\title{
Post-collisional magmatism and ore-forming systems in the Menderes massif: new constraints from the Miocene porphyry Mo-Cu Pınarbașı system, Gediz-Kütahya, western Turkey
}

\author{
Okan Delibaș $^{1} \cdot$ Robert Moritz $^{2} \cdot$ Massimo Chiaradia $^{2} \cdot$ David Selby $^{3} \cdot$ Alexey Ulianov $^{4}$ • \\ Mustafa Kemal Revan ${ }^{5}$
}

Received: 11 May 2016/Accepted: 20 December 2016 /Published online: 31 January 2017

(C) Springer-Verlag Berlin Heidelberg 2016

\begin{abstract}
The Pınarbaşı $\mathrm{Mo}-\mathrm{Cu}$ prospect is hosted within the Pınarbaș intrusion, which is exposed together with the NW-SEtrending Koyunoba, Eğrigöz, and Baklan plutons along the northeastern border of the Menderes massif. The Pınarbaşı intrusion predominantly comprises monzonite, porphyritic granite, and monzodiorite. All units of the Pınarbaşı intrusion have sharp intrusive contacts with each other. The principal mineralization style at the Pınarbaşı prospect is a porphyry-type $\mathrm{Mo}-\mathrm{Cu}$ mineralization hosted predominantly by monzonite and porphyritic granite. The porphyry type Mo-Cu mineralization consists mostly of stockwork and NE- and EW-striking sub-vertical quartz veins. Stockwork-type quartz veins hosted by the upper parts of the porphyritic granite within the monzonite, are typically enriched in chalcopyrite, molybdenite, pyrite, and limonite. The late NE- and EW-striking normal faults cut the stockwork vein system and control the quartz-molybdenite-chalcopyrite-sphal-
\end{abstract}

Okan Delibaș deceased August 23, 2016.

Editorial handling: F. Melcher

Electronic supplementary material The online version of this article (doi:10.1007/s00126-016-0711-7) contains supplementary material, which is available to authorized users.

Robert Moritz

robert.moritz@unige.ch

1 Department of Geological Engineering, Hacettepe University, 06800 Beytepe-Ankara, Turkey

2 Department of Earth Sciences, University of Geneva, Rue des Maraîchers 13, 1205 Geneva, Switzerland

3 Department of Earth Sciences, Durham University, Durham DH1 3LE, UK

4 Institute of Earth Sciences, University of Lausanne, Géopolis, 1015 Lausanne, Switzerland

5 General Directorate of Mineral Research and Exploration (MTA), 06800 Ankara, Turkey erite-fahlore-galena veins, as well as molybdenite-hematitebearing silicified zones. Lithogeochemical and whole-rock radiogenic isotope data $(\mathrm{Sr}, \mathrm{Nd}$ and $\mathrm{Pb})$ of the host rocks, together with Re-Os molybdenite ages $(18.3 \pm 0.1 \mathrm{Ma}-18.2 \pm 0.1 \mathrm{Ma})$ reveal that the monzonitic and granitic rocks of the Pınarbaşı intrusion were derived from an enriched lithospheric mantle-lower crust during Oligo-Miocene post-collisional magmatism. The lithospheric mantle was metasomatised by fluids and subducted sediments, and the mantle-derived melts interacted with lower crust at 35-40 km depth. This mechanism explains the $\mathrm{Mo}$ and $\mathrm{Cu}$ enrichments of the Pınarbașı intrusion during back-arc magmatism. We conclude that the melt of the Pınarbaşı intrusion could have rapidly ascended to mid-crustal levels, with only limited crustal assimilation along major trans-lithospheric faults as a result of thinning of the middle to upper crust during regional extension, and resulted in the development of porphyry-style mineralization during the early Miocene ( $18 \mathrm{Ma})$. The subsequent exhumation history of the Mo-Cu-bearing Pınarbaşı intrusion is attributed to regional-scale uplift, and further exhumation along detachment faults of the associated core complexes during the middle to late Miocene.

Keywords Post-collisional magmatism - Porphyry type mineralization $\cdot$ Ore-forming systems $\cdot$ Re-Os molybdenite ages $\cdot$ Western Anatolia · Turkey

\section{Introduction}

The Aegean Sea region belongs to the Tethys orogenic belt, and it is one of the Cenozoic Mediterranean back-arc basins with the fastest rates of ongoing extension on Earth, resulting in rapid thinning of the continental crust, detachment faulting, exhumation of metamorphic domes, formation of supradetachment sedimentary basins, and abundant post-orogenic magmatism (Bozkurt et al. 1993; Hetzel et al. 1995; Bozkurt and Park 
1997; Ring et al. 1999, 2010; Koçyiğit et al. 2000; Doglioni et al. 2002; Whitney and Bozkurt 2002; Bozkurt and Sözbilir 2004; Dilek et al. 2009; Agostini et al. 2010). Ages of metamorphic dome exhumation and post-orogenic magmatism exhibit a younging from north to south in the Aegean Sea region towards the Hellenic trench (Jolivet et al. 2003; Jolivet and Brun 2010). This geodynamic setting also provided a particularly favorable environment for the concentration of a large variety of metal resources in the Earth's crust, as documented by the abundant $\mathrm{Cu}, \mathrm{Au}$, and $\mathrm{Pb}-\mathrm{Zn}$ deposits and prospects associated with the metamorphic domes and/or post-orogenic magmatic provinces of the Aegean Sea region (Oygür 1997; Arikas and Voudouris 1998; Oygür and Erler 2000; Marchev et al. 2005; Yiğit 2009; Márton et al. 2010; Moritz et al. 2010, 2014; Voudouris et al. 2010; van Hinsbergen and Schmid 2012; Kaiser-Rohrmeier et al. 2013; Sánchez et al. 2016; Fig. 1).

The Middle to Late Cenozoic $\mathrm{Cu}-\mathrm{Mo} \pm \mathrm{Au}$-bearing porphyry systems within different segments of the Tethys metallogenic belt, from the Aegean region through Anatolia to the Lesser Caucasus, are closely associated with the post-collisional evolution of the Tethys metallogenic belt (Konos Cu-Mo, Skouries $\mathrm{Cu}-\mathrm{Au}-\mathrm{Mo}$, Pagoni Rachi Cu-Mo-Ag-Au in Greece: Voudouris et al. 2010, 2013a, b; Kisladag Au-Mo in Turkey: Sillitoe 2002; Yiğit 2009; Kerman Porphyry Cu-Mo belt in Iran: Aghazadeh et al. 2015; Kadjaran Cu-Mo in Armenia: Moritz et al. 2016; Rezeau et al. 2016). The Oligocene to Miocene, Greek Mo-Rebearing porphyry systems in the Cenozoic Mediterranean backarc basin are closely linked to shoshonitic to calc-alkaline magmatism that were produced by sub-continental lithospheric mantle-lower crust interaction within a post-orogenic setting (Kroll et al. 2002; Voudouris et al. 2010, 2013a, b). In particular, the link with the regional tectono-magmatic evolution of Eocene to Oligocene ( 38-29 Ma) ore deposits/prospects of the oldest and northernmost metamorphic dome province of the Aegean region in the Rhodope Massif in Bulgaria and Greece has been addressed in detail (Arikas and Voudouris 1998; Marchev et al. 2005; Márton et al. 2010; Moritz et al. 2010, 2014; KaiserRohrmeier et al. 2013).

The northern zone of the Menderes Massif in Turkey is well endowed with numerous mineral deposits/prospects and a large variety of commodities (Fig. 1), including porphyrytype $\mathrm{Mo}-\mathrm{Cu}-\mathrm{Au}$, skarn-type $\mathrm{Fe}$ and $\mathrm{Pb}-\mathrm{Zn}$, base metal and precious metal epithermal deposits/prospects (Gökce and Spiro 1994; Oygür and Erler 2000; Yiğit 2006, 2009; Delibaș et al. 2012a, b Oyman et al. 2013). Some of the deposits and prospects are spatially associated with postcollisional magmatic activity such as the Ovack $\mathrm{Au}-\mathrm{Ag}$ deposit, with grabens at the Kurșunlu and Emirli $\mathrm{Au}-\mathrm{Ag}-\mathrm{Sb}-\mathrm{Hg}$ bearing prospects, and the hanging- and footwalls of postcollisional detachment faults (Fig. 1; Yiğit 2006). Nevertheless, the link between post-collisional metallogenic evolution, magmatism and extension remains poorly documented and constrained in the Menderes Massif.
This study addresses the petrogenesis of ore-bearing felsic intrusions and the timing of mineralization during postorogenic evolution of the Menderes Massif in western Anatolia. In this contribution, we report field observations from the $\mathrm{Mo}-\mathrm{Cu}$-Pınarbașı prospect, Re-Os molybdenite age data from the main mineralization stage, lithogeochemical, and whole-rock radiogenic isotope data $(\mathrm{Sr}, \mathrm{Nd}$ and $\mathrm{Pb})$ from the associated Oligo-Miocene granitic and monzonitic host rocks. Our aim is to constrain the timing of mineralization, and its genetic link with the ore-associated magmatic rocks and the geodynamic evolution of the Gediz-Pınarbașı region.

\section{Regional geology}

Following final accretion of the Gondwana-derived Sakarya block to the southern Eurasian margin during the Late Cretaceous-Paleocene (Şengör and Yilmaz 1981; Okay and Tüysüz 1999), western Anatolia underwent widespread extension from the Oligo-Miocene to the present. Previous studies have concluded that the complex extensional tectonic evolution has resulted in exhumation of metamorphic core complexes, emplacement of felsic intrusions along shear zones, block faulting and graben formation (Bozkurt et al. 1993; Hetzel et al. 1995; Ring et al. 1999; Koçyiğit et al. 2000). Western Anatolia is segmented into several thrust-bounded metamorphic zones, and includes from north to south: the Tavşanlı zone, the Afyon zone, and the Menderes Massif (Fig. 1, inset; Șengör et al. 1984; Okay et al. 1998; Sherlock 1999; Okay 2008; van Hinsbergen 2010). The oldest units in the region are the Menderes Massif metamorphic rocks, which are tectonically overlain by the Lycian Nappes in the south and the oceanic remnants of the Neo-Tethys in the north (Collins and Robertson 1997; Bozkurt 2004). The northern and northeastern borders of the Menderes Massif are crosscut by Cenozoic diorite, quartz diorite, monzonite, granodiorite and granite. Three main magmatic episodes are recognized: 1) middle to late Eocene, 2) Oligo-Miocene, and 3) middle-late Miocene to recent (Innocenti et al. 2005; Ring and Collins 2005; Hasözbek et al. 2010; Karaoğlu et al. 2010; Altunkaynak et al. 2012a, b). Although their origin has been hotly debated, the Eocene calcalkaline felsic intrusions (55-38 Ma) are generally attributed to subduction-related magmatism, partly sourced by metasomatised lithospheric mantle during convergence and subsequent collision of the Sakarya and Anatolide-Tauride blocks along the Izmir-Ankara subduction zone (IASZ) (Harris et al. 1994; Aldanmaz et al. 2000; Koprubasi and Aldanmaz 2004; Altunkaynak et al. 2012b).

The duration of the second, Oligo-Miocene calc-alkaline to high-K calc-alkaline magmatic cycle is well constrained between $\sim 24.0$ and 19.5 Ma with U-Pb zircon ages from granite (Ring and Collins 2005; Hasözbek et al. 2010; Altunkaynak et al. 2012a) and ${ }^{40} \mathrm{Ar} /{ }^{39} \mathrm{Ar}$ (hornblende, biotite) ages record cooling 


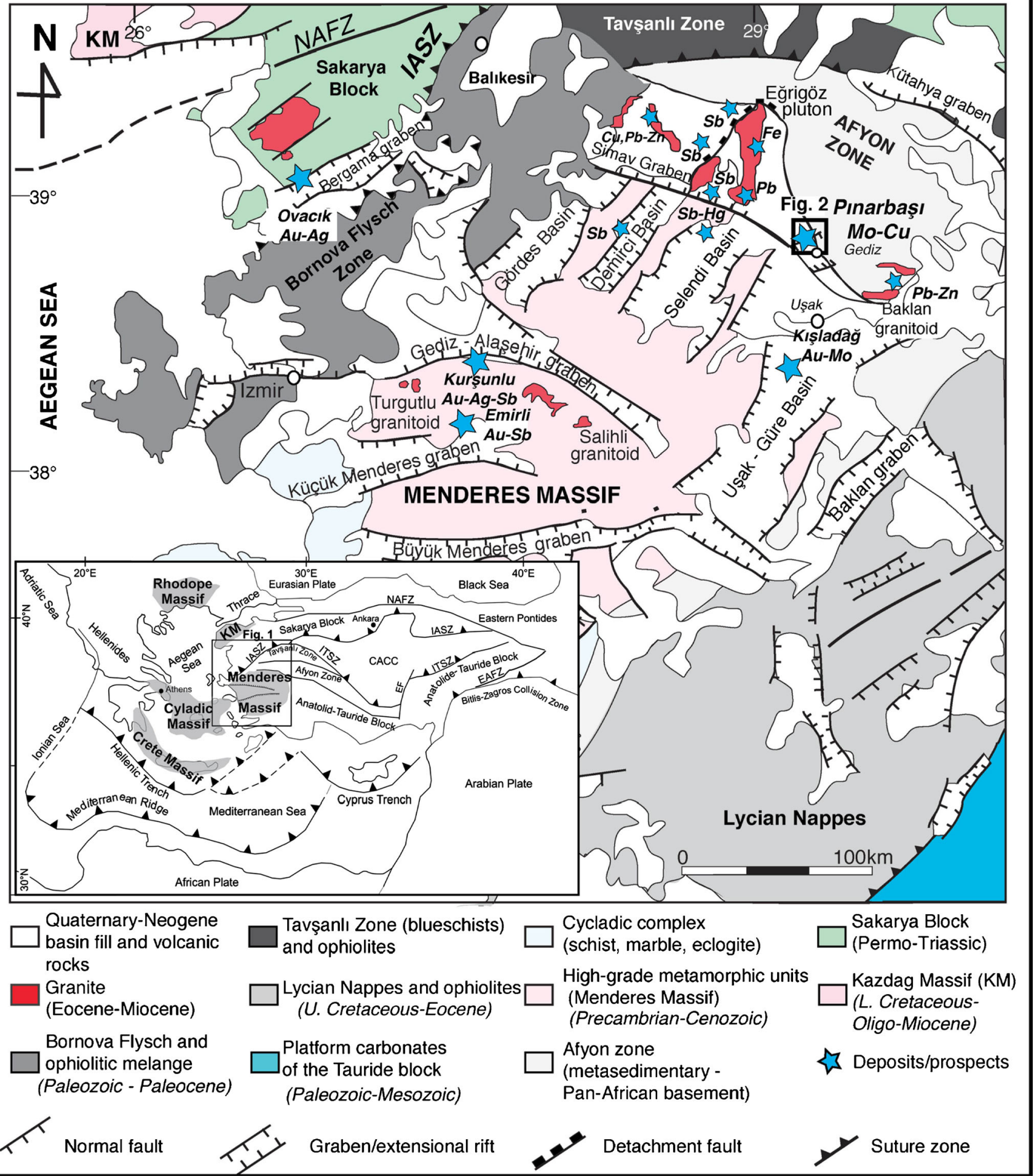

Fig. 1 Simplified regional tectonic-geological map of western Anatolia and location of the Pınarbaş1 Mo-Cu prospect and major ore deposits/prospects related with the main tectonic structures in western Anatolia (modified after Dilek et al. 2009; Öner and Dilek 2011). Inset shows main plate boundaries, major suture zones, metamorphic massifs and tectonic units of the Aegean and eastern Mediterranean region (modified after Dilek 2006; Dilek and

Sandvol 2009; Okay and Tüysüz 1999) BFZ: Bornava flysch zone; CACC: Central Anatolian Crystalline Complex; EAFZ: East Anatolian fault zone; EF: Ecemis fault; KA: Kazdağ massif; IASZ: Izmir-Ankara suture zone; ITSZ: Inner-Tauride suture zone; MM: Menderes massif; NAFZ: North Anatolian fault zone 
ages of the Oligo-Miocene granites that range between $\sim 25$ and $18 \mathrm{Ma}$, indicating fast cooling (Isik et al. 2004; Aydoğan et al. 2008; Altunkaynak et al. 2012a). However, the origin of the Oligo-Miocene magmatism remains open to question. Several models have been proposed, including: 1) back-arc magmatism during southward roll-back and retreat, as the African and Eurasian plates were converging, resulting in partial melting of the lower crust during asthenospheric upwelling (Fytikas et al. 1984; Delaloye and Bingöl 2000; Pe-Piper and Piper 2001, 2007; Jolivet and Brun 2010; Ring et al. 2010; Jolivet et al. 2015); 2) decompressional melting related to orogenic collapse of an overthickened crust, at the late Oligocene-early Miocene transition (Seyitoglu et al. 1992; Seyitoglu 1997); and 3) postcollisional magmatism sourced by melting of lithospheric mantle metasomatised during the preceding subduction stage, and induced by asthenospheric upwelling. The latter is attributed to the Sakarya-Taurides-Anatolides continent collision in the north and the subsequent extensional stage related to subduction of the Aegean slab along the Hellenic arc (Aldanmaz et al. 2000; Altunkaynak and Dilek 2006; Dilek et al. 2009). The OligoMiocene magmatism accompanied a two-stage regional extension of western Anatolia, starting with late Oligocene to early Miocene detachment faulting, such as the Simav fault zone (Fig. 1), and late Oligocene to middle Miocene core complex exhumation in the Menderes Massif, followed by graben formation with high-angle normal faulting from middle to late Miocene (Pourteau et al. 2010; Fig. 1). The general agreement is that the local granitic intrusions, named Eğrigöz, Alaçam and Koyunoba (Fig. 1), are syn-tectonic, and that they intruded Paleozoic basement along the footwall of the Simav detachment fault zone during early extension and metamorphic core exhumation in the early Miocene (Isik et al. 2004; Dilek et al. 2009; Erkül 2010; Erkül et al. 2013).

The last pulse of Cenozoic magmatism in the region consists of intraplate shoshonitic to mildly alkaline and following OIBtype magmatism, during thinning of the Aegean-Anatolian lithosphere in response to extension since the middle-late Miocene (Doglioni et al. 2002; Innocenti et al. 2005; Agostini et al. 2007, 2010; Karaoğlu et al. 2010; Ersoy and Palmer 2013). The middle-late Miocene to early Pliocene pulse of magmatism is mainly mildly alkaline to shoshonitic in nature and it shows a within-plate character (Innocenti et al. 2005; Helvac1 et al. 2009). On the other hand, the early Pliocene to Quaternary phase of magmatism comprises sodic and potassic magmatism and it displays clear OIB-type signatures (Alici et al. 2002; Innocenti et al. 2005; Ersoy and Palmer 2013).

\section{Geological setting of the Pınarbașı Mo-Cu prospect}

In the Gediz-Pınarbaşı region, the stratigraphic column comprises, from bottom to top, Menderes Massif metamorphic rocks and low-temperature, high-pressure meta-sedimentary units of the Afyon zone, followed by the Triassic-Jurassic Kırkbudak Formation composed of alternating sandstone, siltstone and limestone units with an estimated thickness of 200 to $750 \mathrm{~m}$, and a Late Triassic to Maastrichtian dolomitized, platform-type limestone unit, known as the Budağan limestone with an estimated thickness of 150 to $600 \mathrm{~m}$ (Akdeniz and Konak 1979; Okay et al. 1996; Candan et al. 2005). These stratigraphic units are overthrusted by Cretaceous to Paleocene ophiolitic mélange units, mostly comprising radiolarite, large limestone-marble blocks, tuffite, and peridotite with a thickness of more than $750 \mathrm{~m}$ (Akdeniz and Konak 1979). These rocks were intruded by early Miocene felsic rocks and their sub-volcanic equivalents, including the Eğrigöz, Koyunoba, and Pınarbașı intrusions and the Simav volcanic rocks (Figs. 1 and 2a-b). The NW-trending Mo-Cu-bearing, multiphase, calc-alkaline Pınarbaşı intrusion is crosscut by NW- and NS-striking andesitic, dacitic, and aplitic dykes, and NE- and EW-striking Mo-Cu-bearing quartz veins, whereas the limestone and mélange units are crosscut by NWtrending porphyry dikes (Delibaş et al. 2012a, b). The eastern zone of the mapped area is dominated by Neogene and Quaternary volcano-sedimentary cover sequences (Fig. 2a).

The NW-trending active Simav and Kutahya fault zone next to the Pinarbaşı prospect resulted in complex EW-, NW-, and NE-oriented block faulting (Tokay and Doyuran 1979; Fig. 1, and inset in Fig. 2). The Pınarbaşı intrusion is exposed on the northwestern shoulder of the Yenidoğmuş-YeniGediz graben, and is controlled by the NE-striking Eskigediz normal fault and the EW- to NW-oriented Șaphane normal fault zone, which are associated with graben formation (Gürboğa et al. 2013; inset in Fig. 2). The latter fault zone hosts the Șaphane deposit, which is the largest epithermal alunite deposit of Turkey (Mutlu et al. 2005). Three generations of fault systems have been recognized, including EW- and NW-striking normal faults, NE-trending normal faults, dipping $70-80^{\circ}$ to the NW (Fig. 3a-b), and late-stage NS-, NW-, and NE-striking strike-slip local fault systems, which are largely developed along the vertical contacts between the intrusion and limestone, and which crosscut the hydrothermal alteration zones as well as earlier faults. The Pınarbaşı intrusion is strongly mylonitized along its contact with the intensely silicified country rock (Fig. 3c). This masks the contact between the intrusion and its country rocks, and conceals the late contact metamorphism along the margins of the intrusion (Delibaş et al. 2012a; Fig. 3c). However, 0.5 to $1 \mathrm{~m}$-wide skarn zones containing garnet, epidote, pyroxene, calcite, and magnetite are developed along the contacts of the NW-trending porphyritic dykes crosscutting the limestone and the mélange units (Fig. 3d).

The Pınarbașı intrusion primarily comprises monzonite, porphyritic granite, and monzodiorite (Delibaș et al. 2012a, b), which have sharp intrusive contacts with each other (Fig. 3a). They contain roughly oval, fine-grained dioritic enclaves, with sharp contacts with their host rocks. The largest intrusive body in the area is a fine- to medium-grained monzonite with a largely equigranular texture. It predominantly contains highly 


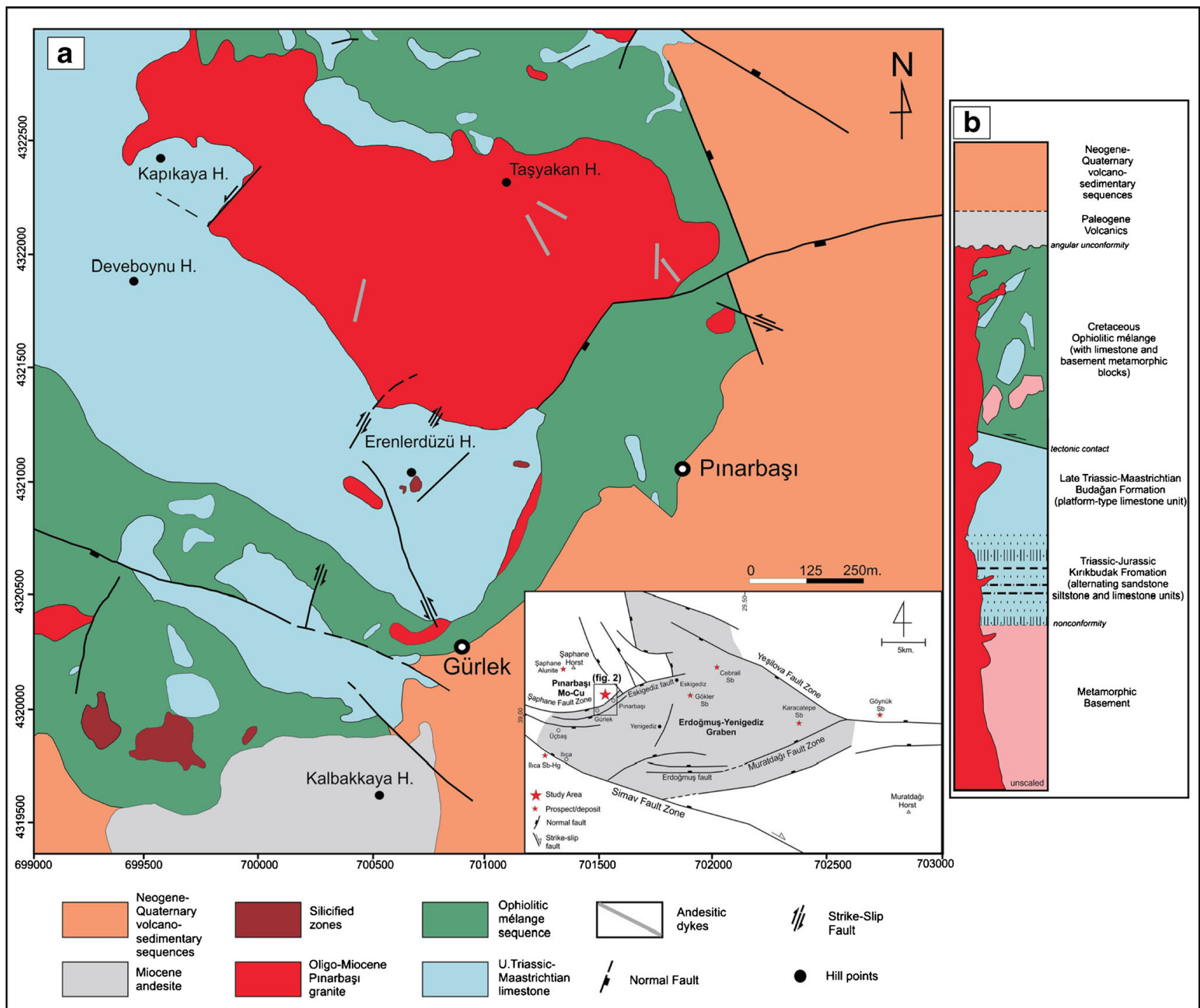

Fig. 2 a Simplified geological map of the Pınarbașı (Gediz) prospect (Delibaș et al. 2012a, b), inset shows location of the Pınarbașı Mo-Cu prospect within the Erdoğmuş-Yenigediz graben (modified after Gürboğa et al. 2013), b generalized stratigraphic column of the study area (modified after Akdeniz and Konak 1979; Delibaş et al. 2012a, b) sericitized euhedral to subhedral plagioclase, subhedral K-feldspar, subhedral to euhedral amphibole, biotite, pyroxene, minor quartz, and accessory apatite. Epidote, calcite, chlorite, and sericite are alteration products of the main mineral assemblage. A porphyritic granite cutting the monzonite is exposed in the western part of the area (Fig. 3e). The intrusion of the porphyritic granite into the monzonite resulted in the formation of an intrusion breccia (Delibaș et al. 2012a; Fig. 3f). The porphyritic granite is characterized by a more pronounced porphyritic texture, consisting of plagioclase, biotite and K-feldspar phenocrysts within a fine-grained matrix consisting of K-feldspar, plagioclase, biotite, amphibole, and quartz. The monzonite and porphyritic granite are cut by bodies of dark-gray diorite and monzodiorite with an equigranular to porphyritic texture. They have the same mineralogical composition as the dioritic enclaves and generally consist of sericitized plagioclase, amphibole, biotite, pyroxene, and minor quartz.

\section{The Pınarbașı porphyry Mo-Cu-type prospect}

The Pınarbașı Mo-Cu prospect is hosted by the Pınarbaşı intrusion, which is exposed approximately $20 \mathrm{~km}$ southeast of the NW-trending active Simav fault zone. The latter fault also hosts small to mid-scale high- and low-sulfidation epithermal and $\mathrm{Cu}-$ $\mathrm{Pb}-\mathrm{Zn}$ vein-type mineralization within the southern sector of the Afyon zone (Oygür and Erler 2000; Fig. 1). Based on drill hole data, the $\mathrm{Cu}$ and Mo contents of the prospect vary between 374 and 34,800 ppm, and between 106 and 2200 ppm, respectively (Delibaș et al. 2012b). 


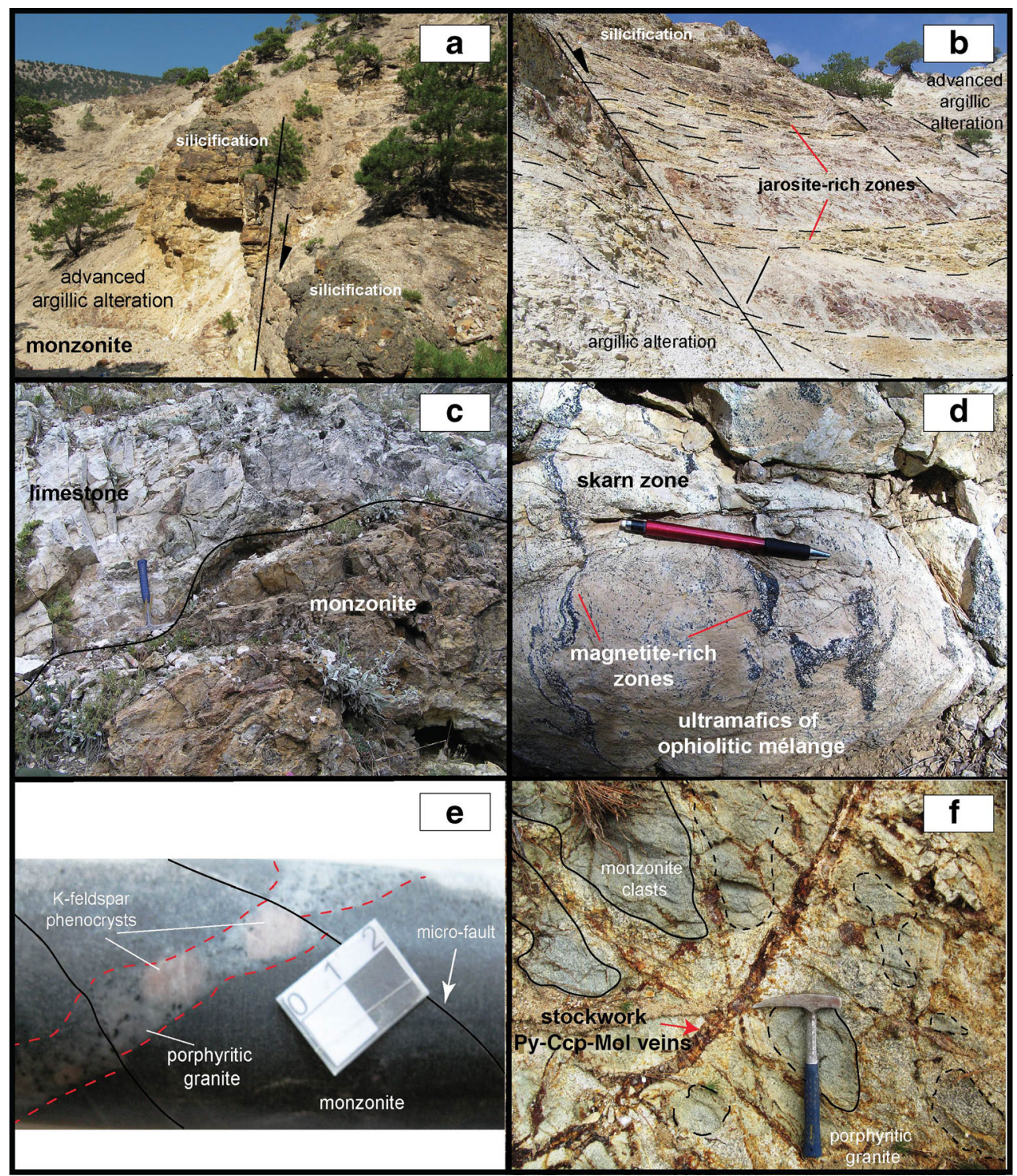

Fig. 3 Field relationships at the Pınarbaşı prospect. a EW-trending normal fault system cutting monzonite and associated silicified zones, b NE-trending late stage normal fault cutting supergene argillic alteration zones, $\mathbf{c}$ contact relationships between monzonite and limestone, $\mathbf{d}$ magnetite-epidote-pyroxene skarn zones along contacts of a NW-

The principal mineralization style at the Pınarbaşı prospect is a porphyry Mo-Cu type mineralization hosted predominantly by monzonite and porphyritic granite. Field, mineralogical, and lithogeochemical studies have also revealed the presence of $\mathrm{Pb}$ and $\mathrm{Zn}$ enrichments up to $6.7 \mathrm{wt} \%$ and $7700 \mathrm{ppm}$, respectively, within the Budağan limestone (Oygür and Erler 2000; Delibaş et al. 2012a, b). In addition, $\mathrm{Sb}, \mathrm{Ag}$ and $\mathrm{Au}$ grades up to $1210 \mathrm{ppm}, 12 \mathrm{ppm}$, and $1320 \mathrm{ppb}$, respectively, have been reported within the silicified zones along the NW-striking, normal and strike-slip faults cutting the limestone blocks of the ophiolitic mélange units and $\mathrm{Sb}, \mathrm{Ag}, \mathrm{Au}$ and $\mathrm{Pb}$-rich silicified zones within limestone blocks mainly show lattice textures (e.g., primary bladed calcite, ghost bladed quartz, lattice bladed quartz), indicating a trending porphyritic granite dyke with ultramafic rocks of the ophiolitic mélange unit, e drill core sample showing porphyritic granite crosscutting monzonite, $\mathbf{f}$ intrusion breccia formed during emplacement of porphyritic granite into monzonite

low-sulfidation epithermal mineralization at relatively shallow depths (Delibaș et al. 2012b).

The porphyry-type Mo-Cu mineralization consists mostly of stockwork and NE- and EW-striking sub-vertical quartz veins (Fig. 4a-b). Stockwork-type quartz veins within the upper parts of the porphyritic granite typically contain chalcopyrite, molybdenite, pyrite, and limonite. Late NE- and EW-striking normal faults, crosscutting the stockwork mineralization, host quartzmolybdenite-chalcopyrite-sphalerite-sulfosalts-galena veins and molybdenite-hematite-bearing silicified zones (Fig. 4c-e). Potassic, sericitic, and argillic alterations are associated with the Mo-Cu mineralization (Oygür and Erler 2000; Delibaș et al. 2012a, b). The local potassic alteration zone within porphyritic 
granite of the Pınarbaşı intrusion is characterized by small magnetite, biotite, and 1-5 cm thick K-feldspar veins (Fig. 5a-b). Sericitic alteration is developed along the NE- and EW-striking ore-controlling faults, where advanced argillic alteration is less intense, and it is dominated by sericite-muscovite, pyrite, hematite, and small quartz veinlets (Figs. 4b-c and 5c-d). Sericitic alteration grades locally into intense silicification, which contains small molybdenite-bearing stockwork quartz veinlets. The intensity of silicification decreases away from the main fault zones. Creamy to white advanced argillic alteration predominates at Pınarbaşı and overprints the sericitic and potassic alterations. It primarily comprises pyrophyllite, tabular alunite, fluorite, kaolinite, and illite (Fig. 5e-f). Jarosite, smectite, and Fe-oxides along the late-stage normal and strike-slip faults are interpreted as supergene alteration. Based on field observations, mineralization styles, and alteration types, the Pınarbaşı prospect is interpreted as a porphyry-style $\mathrm{Mo}-\mathrm{Cu}$ mineralization, telescoped by lowsulfidation epithermal $\mathrm{Sb} \pm \mathrm{Ag} \pm \mathrm{Au} \pm \mathrm{Pb}$ mineralization and an intense advanced argillic alteration zone. Late supergene alteration along younger fault zones overprints the earlier associations (Oygür and Erler 2000; Delibaș et al. 2012a).

\section{Results}

Seventeen fresh rock samples from the Pınarbaşı granitoid were selected for whole-rock lithogeochemistry analysis. Samples showing hydrothermal alteration effects were removed and we used plutonic and subvolcanic rock samples revealing loss of ignition (LOI) below $2.0 \mathrm{wt}$ \% for petrologic interpretations to avoid potential hydrothermal alteration effects. Twelve whole-rock powder samples were analyzed for

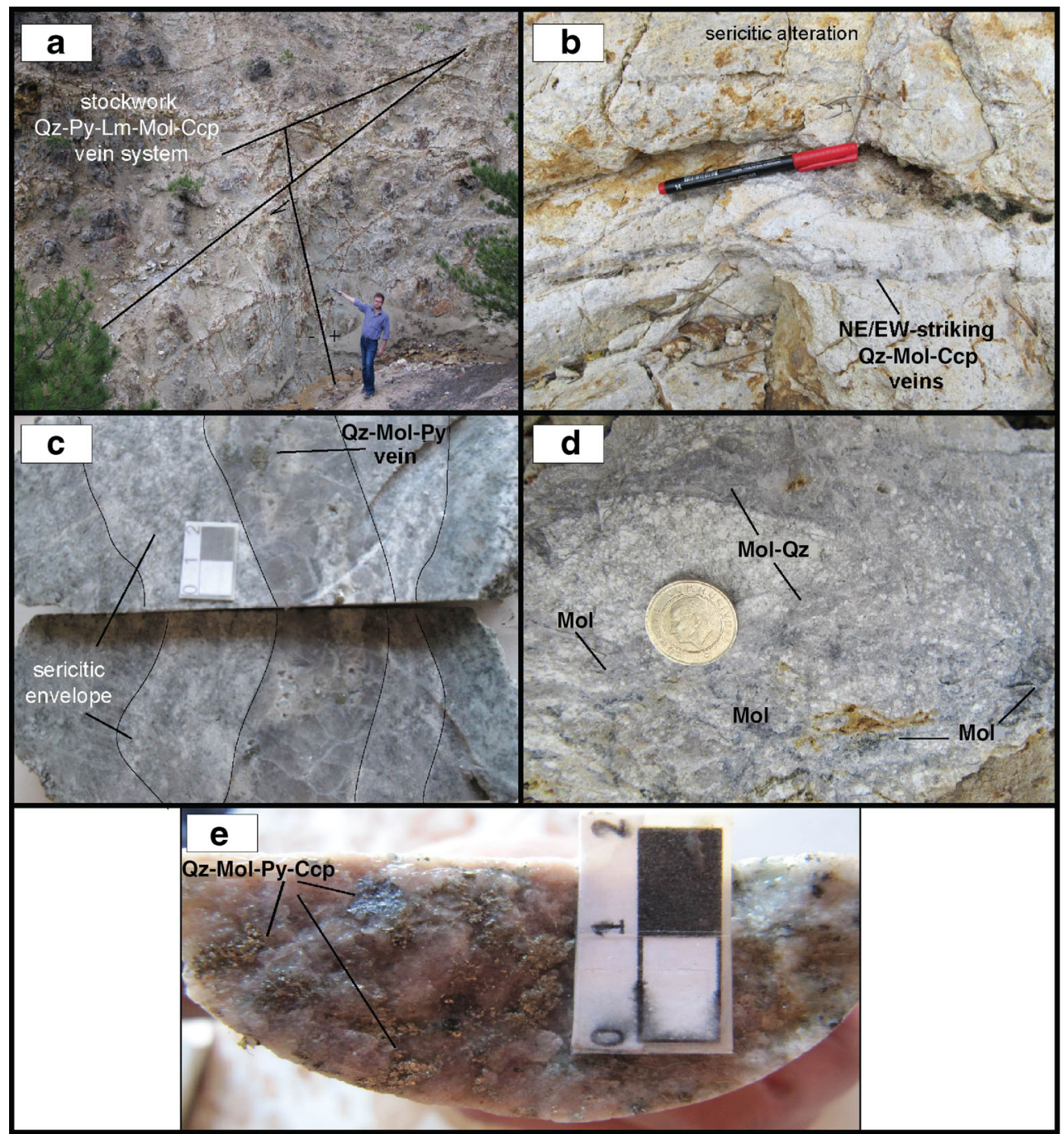

Fig. 4 Different mineralization types at the Pınarbașı prospect. a Pyritemolybdenite and chalcopyrite-bearing stockwork quartz-limonite veins crosscutting monzonite with intense sericitic alteration and stockworktype mineralization crosscut by late stage strike-slip and normal fault systems, b NE and EW-striking quartz-molybdenite \pm chalcopyrite veins crosscutting porphyritic granite, c drill core sample with quartzmolybdenite vein surrounded by sericitic alteration, d molybdenitebearing intensely silicified zone, e drill core sample consisting of a quartz-molybdenite-pyrite-chalcopyrite vein (Qz: quartz, Py: pyrite, Ccp: chalcopyrite, Mol: molybdenite, Lm: limonite) 


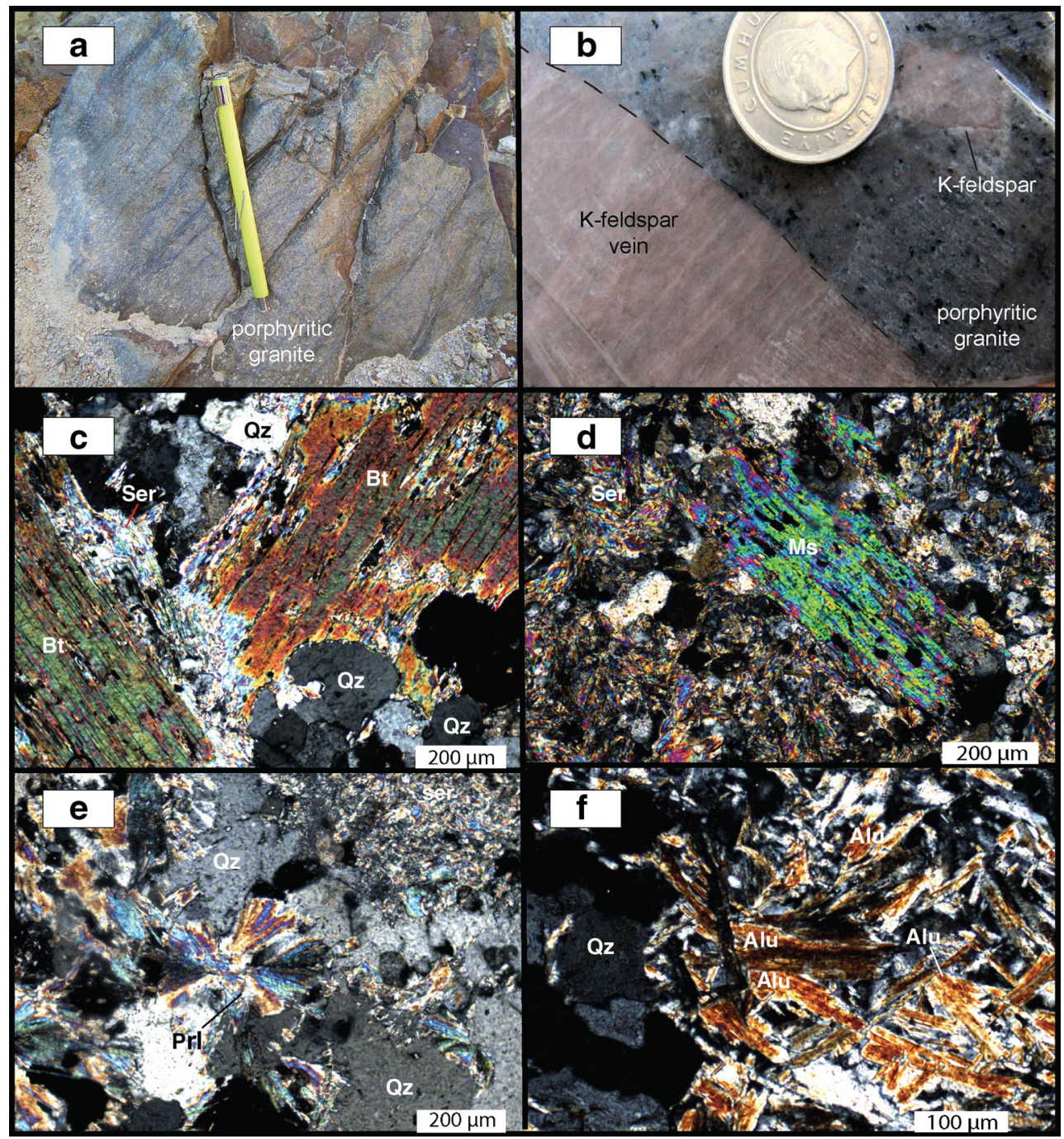

Fig. 5 Alteration styles and alteration minerals from the Pınarbașı prospect. a Magnetite veins crosscutting porphyritic granite, b Kfeldspar vein crosscutting porphyritic granite, $\mathbf{c}$ biotite replaced by sericite around quartz-molybdenite veins, $\mathbf{d}$ muscovite within sericitic

radiogenic isotopic compositions $(\mathrm{Sr}, \mathrm{Nd}, \mathrm{Pb})$. Radiogenic isotope analyses were conducted at the University of Geneva, Switzerland. We also report two new Re-Os molybdenite ages from the main mineralization stage. The ${ }^{187}$ Re and ${ }^{187}$ Os concentrations in molybdenite were determined in the Source Rock and Sulfide Geochronology and Geochemistry Laboratory at the University of Durham, United Kingdom. The details of the analytical techniques are summarized in Online Resource 1 and the major and trace element data of the Pınarbaşı intrusion are listed in Online Resources 2 and 3.

\section{Whole-rock geochemistry of the Pınarbaşı intrusion}

The Pınarbaşı intrusive rocks range in composition from dioritegranodiorite to monzonite with $\mathrm{SiO}_{2}$ contents varying from 61 to 69 wt.\% (Fig. 6a). All samples of the Pinarbași intrusion straddle the boundary between alkaline and subalkaline series and show a alteration zones, e fibroradial pyrophyllite crystals within the advanced argillic alteration zone, $\mathbf{f}$ tabular alunite crystals within the advanced argillic alteration zone (Qz: quartz, Bt: biotite, Ser: sericite, Ms.: muscovite, Prl: pyrophyllite, Alu: alunite)

calc-alkaline trend on the AFM diagram (Fig. 6a-b). In addition, they belong to the high-K calc-alkaline series on the $\mathrm{K}_{2} \mathrm{O}$ vs $\mathrm{SiO}_{2}$ classification diagram of Peccerillo and Taylor (Peccerillo and Taylor 1976; Fig. 6c). The Pınarbaşı samples are also transitional metaluminous to peraluminous based on $\mathrm{A} / \mathrm{CNK}\left(\mathrm{Al}_{2} \mathrm{O}_{3} /\right.$ $\left.\left(\mathrm{CaO}+\mathrm{Na}_{2} \mathrm{O}+\mathrm{K}_{2} \mathrm{O}\right)\right)$ values varying from 0.9 to 1.2 . The porphyritic granite members, i.e. the most evolved samples, of the Pınarbaşı intrusion are mildly peraluminous, whereas the monzonite, and enclave samples are predominantly metaluminous and display similarities with western Aegean Oligo-Miocene felsic intrusions (Fig. 6d). On binary plots, the samples show decreasing $\mathrm{Al}_{2} \mathrm{O}_{3}, \mathrm{Fe}_{2} \mathrm{O}_{3}, \mathrm{MgO}, \mathrm{CaO}, \mathrm{TiO}_{2}$, and $\mathrm{P}_{2} \mathrm{O}_{5}$ contents with increasing $\mathrm{SiO}_{2}$ concentrations. Despite scattered variations, $\mathrm{Sr}, \mathrm{V}$, and $\mathrm{Zr}$ decrease with increasing $\mathrm{SiO}_{2}$, whereas $\mathrm{Th}$ and $\mathrm{Ni}$ display no marked correlation with increasing $\mathrm{SiO}_{2}$ (see Online Resource 4). All samples from the Pınarbaşı intrusion display similar trace element patterns 

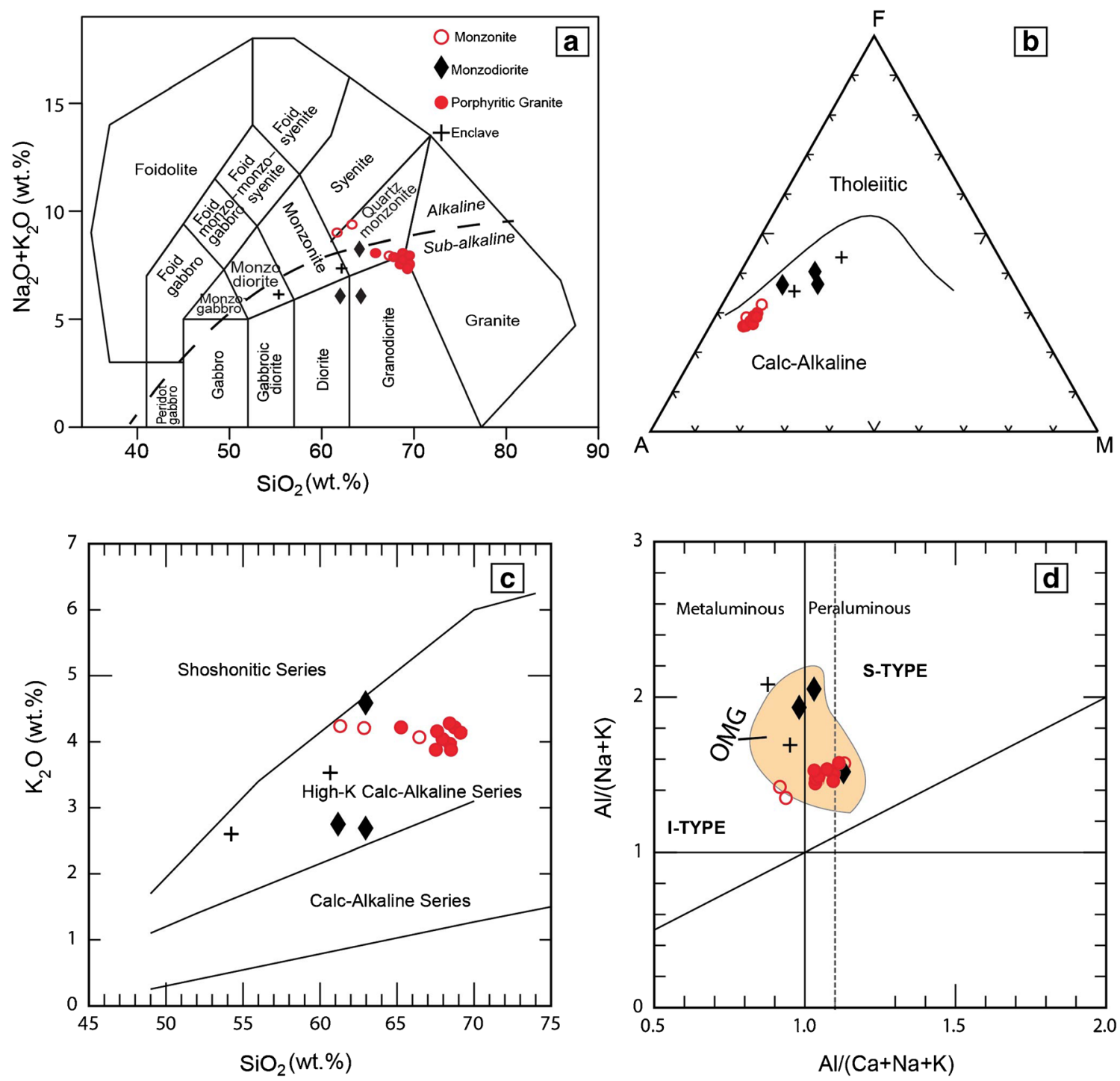

Fig. 6 Geochemical classification and discrimination diagrams including magmatic rock samples from the Pınarbaşı prospect. a $\mathrm{SiO}_{2}$ (wt.\%) versus $\mathrm{Na}_{2} \mathrm{O}+\mathrm{K}_{2} \mathrm{O}$ (wt.\%) classification diagram (Middlemost 1994), b AFM plot of Irvine and Baragar (1971), A: $\mathrm{Na}_{2} \mathrm{O}+\mathrm{K}_{2} \mathrm{O}$ (wt.\%); $\mathrm{F}: \mathrm{FeO}_{\mathrm{t}}$ (wt.\%); $\mathrm{M}: \mathrm{MgO}$ (wt.\%), $\mathbf{c} \mathrm{K}_{2} \mathrm{O}$ (wt.\%) versus $\mathrm{SiO}_{2}$ (wt.\%) diagram for

(Fig. 7a). They are enriched in large-ion lithophile elements (LILEs; e.g., Th, K, Ba) and are depleted in high-field strength elements (e.g., $\mathrm{Nb}, \mathrm{Ta}, \mathrm{P}$, and Ti). Furthermore, they have trace element patterns similar to those of the upper crust. The Pınarbaş1 samples display a pronounced light rare earth element (LREEs) enrichment with respect to middle (MREEs) and heavy rare earth elements (HREEs) $\left(\mathrm{La}_{\mathrm{N}} / \mathrm{Yb}_{\mathrm{N}}=10-36, \mathrm{La}_{\mathrm{N}} / \mathrm{Gd}_{\mathrm{N}}=7.2-13\right)$, with weak to strong negative Eu anomalies $\left(\mathrm{Eu} / \mathrm{Eu}^{*}=0.66-0.85\right)$, and minor depletion in MREEs $\left(\mathrm{Gd}_{\mathrm{N}} / \mathrm{Yb}_{\mathrm{N}}=1.13-1.59\right)$ (Fig. $\left.7 \mathrm{~b}\right)$.

\section{Whole-rock $\mathrm{Sr}, \mathrm{Nd}$, and $\mathrm{Pb}$ isotopic compositions}

The analytical techniques used in the study are summarized in Online Resource 1. Sr, $\mathrm{Nd}$, and $\mathrm{Pb}$ isotope ratios for whole-rock the samples of Pınarbaşı granitoid (discrimination lines separating the tholeiitic, calc-alkaline, high-K calc-alkaline and shoshonitic series are from Peccerillo and Taylor 1976), d Al/(Ca + Na + K) versus $\mathrm{Al} /(\mathrm{Na}+$ $\mathrm{K})$ molar discrimination diagram (OMG: Oligo-Miocene Granitoids; Altunkaynak et al. 2012a)

samples from Pınarbaşı (granitic and monzonitic) are presented in Tables 1 and 2. The age-corrected initial $\mathrm{Sr}, \mathrm{Nd}$, and $\mathrm{Pb}$ isotopic ratios were calculated for an age of $20 \mathrm{Ma}$, which is generally accepted for Oligo-Miocene felsic intrusions in the region. The ${ }^{87} \mathrm{Sr} /{ }^{86} \mathrm{Sr}_{(\mathrm{i})}$ of the porphyritic granite samples range from 0.70774 to 0.70923 , whereas the initial $\mathrm{Sr}$ isotope ratios of the monzonite and monzodiorite samples range from 0.70718 to 0.70820 (Table 1). The ${ }^{143} \mathrm{Nd} /{ }^{144} \mathrm{Nd}_{(i)}$ ratios of the porphyritic granite samples vary from 0.51234 to $0.51242(\varepsilon \mathrm{Nd}$ values of -3.85 to -5.38 ), and the ${ }^{143} \mathrm{Nd} /{ }^{144} \mathrm{Nd}_{(\mathrm{i})}$ ratios of monzonite and monzodiorite samples vary from 0.51228 to $0.51245(\varepsilon \mathrm{Nd}$ values of -3.22 to -6.45$)$. A dioritic enclave sample has a ${ }^{87} \mathrm{Sr}^{86} \mathrm{Sr}_{(\mathrm{i})}$ ratio of 0.70718 and a ${ }^{143} \mathrm{Nd} /{ }^{144} \mathrm{Nd}_{(\mathrm{i})}$ ratio of 0.51244 ( $\varepsilon \mathrm{Nd}$ value of -3.4$)$. The evolved samples from the 

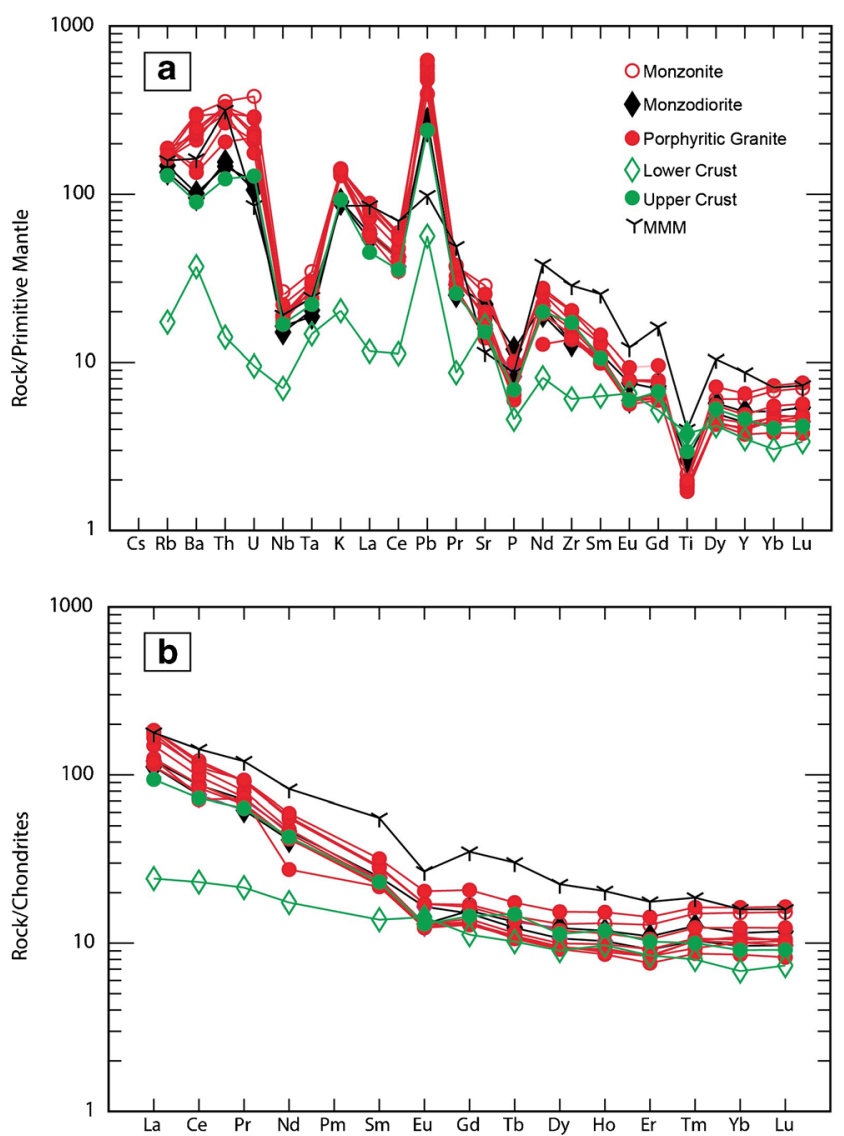

Fig. 7 a Primitive mantle-normalized (Sun and McDonough 1989) multi-element patterns for rock samples from the Pınarbaşı pluton, $\mathbf{b}$ chondrite-normalized (Sun and McDonough 1989) REE patterns for rock samples from the Pınarbaşı pluton (Upper and Lower Crust data from Rudnick and Gao 2003; data for Menderes Massif metamorphic rocks from Çoban et al. 2012)

Pınarbașı intrusion (Gtk-15 with 68.5 wt.\% $\mathrm{SiO}_{2}$, and Gtk-06 with 68.7 wt.\% $\left.\mathrm{SiO}_{2}\right)$ have higher ${ }^{87} \mathrm{Sr} /{ }^{86} \mathrm{Sr}_{(\mathrm{i})}$ ratios $(0.70923$ and 0.70855 , respectively) even though there are no significant differences in the ${ }^{143} \mathrm{Nd} /{ }^{144} \mathrm{Nd}_{(\mathrm{i})}$ ratios (Gtk-06: 68.7 wt.\% $\mathrm{SiO}_{2}$ with $0.51236{ }^{143} \mathrm{Nd} /{ }^{144} \mathrm{Nd}_{(\mathrm{i})}$ ratio and Gtk-09: 61.2 wt.\% $\mathrm{SiO}_{2}$ with $0.51245{ }^{143} \mathrm{Nd} /{ }^{144} \mathrm{Nd}_{(\mathrm{i})}$ ratio) between the most and least evolved samples of the Pınarbaș1. Figure 8a shows the initial $\mathrm{Sr}$ and $\mathrm{Nd}$ isotopic compositions of the samples, the potential source reservoirs, Oligo - Miocene (OMG) and Eocene felsic intrusions (EOG), Simav volcanic rocks (SMV), Baklan felsic intrusions (BG), and Kula volcanic rocks (KV). In the $\mathrm{Nd}$ vs $\mathrm{Sr}$ isotope space (Fig. 8a), the Pınarbașı intrusion samples fall along an array indicating crustal contamination of mantle-derived melts. The correlation between ${ }^{143} \mathrm{Nd} /{ }^{144} \mathrm{Nd}_{(\mathrm{i})}$ and ${ }^{87} \mathrm{Sr} /{ }^{86} \mathrm{Sr}_{(\mathrm{i})}$ ratios is slightly negative and all samples overlap with the compositions of the Eastern Mediterranean Sea Sediments (EMMS), OMG, and SMV (Fig. 8a). In contrast, they have higher ${ }^{87} \mathrm{Sr} /{ }^{86} \mathrm{Sr}_{(\mathrm{i})}$ and ${ }^{143} \mathrm{Nd} /{ }^{144} \mathrm{Nd}_{(\mathrm{i})}$ ratios than those of the BG samples.

The Pınarbașı samples yield a relatively restricted range of ${ }^{206} \mathrm{~Pb} /{ }^{204} \mathrm{~Pb}_{(\mathrm{i})},{ }^{207} \mathrm{~Pb} /{ }^{204} \mathrm{~Pb}_{(\mathrm{i})}$, and ${ }^{208} \mathrm{~Pb} /{ }^{204} \mathrm{~Pb}_{(\mathrm{i})}$ ratios (Fig. $8 \mathrm{~b}-$ c). The monzonite and monzodiorite sample ranges are, respectively, 18.935-19.021, 15.716-15.724 and 39.070-39.091, and the porphyritic granite sample ranges are 18.936-18.951, 15.717-15.721 and 39.068-39.082, respectively (Table 2). A dioritic enclave sample has the least radiogenic ${ }^{206} \mathrm{~Pb} /{ }^{204} \mathrm{~Pb}_{(\mathrm{i})}$, ${ }^{207} \mathrm{~Pb} /{ }^{204} \mathrm{~Pb}_{(\mathrm{i})}$, and ${ }^{208} \mathrm{~Pb} /{ }^{204} \mathrm{~Pb}_{(\mathrm{i})}$ ratios of $18.939,15.717$, and 39.065, respectively. All samples plot above the Upper Crust curve (Zartman and Doe 1981) and partly overlap with the compositions of the basement metamorphic rocks, the Eğrigöz granitoid (EG), and the SMV (Fig. 8b). In contrast, they have more radiogenic ${ }^{206} \mathrm{~Pb} /{ }^{204} \mathrm{~Pb}_{(\mathrm{i})}$, and ${ }^{207} \mathrm{~Pb} /{ }^{204} \mathrm{~Pb}_{(\mathrm{i})}$ ratios than the Kula volcanic rocks $(\mathrm{KV})$. On the ${ }^{206} \mathrm{~Pb} /{ }^{204} \mathrm{~Pb}_{(\mathrm{i})}$ vs ${ }^{208} \mathrm{~Pb} /{ }^{204} \mathrm{~Pb}_{(\mathrm{i})}$ diagram (Fig. 8c), they also intersect the EMSS field comprising Sahara desert dust, Nile sediments, and minor Tethyan ophiolitic and arc volcanic rocks from the Hellenic trench, which were traced in Stromboli volcanic rocks along the Aeolian arc (Klaver et al. 2015), and have a less radiogenic ${ }^{208} \mathrm{~Pb} /{ }^{204} \mathrm{~Pb}_{(\mathrm{i})}$ ratio compared to basement metamorphic rocks (Fig. 8c). In Fig. 8d, all samples from Pınarbașı display ${ }^{87} \mathrm{Sr} /{ }^{86} \mathrm{Sr}_{(\mathrm{i})}$ trending towards the subducted sediment-rich Enriched Mantle II end member (EM2; Zindler and Hart 1986), the Global Subducted Sediments end member (GLOSS; Plank and Langmuir 1998),

Table 1 Isotope data ( $\mathrm{Sr}$ and $\mathrm{Nd}$ ) of magmatic whole rock samples from the Pınarbașı intrusion

\begin{tabular}{|c|c|c|c|c|c|c|c|c|c|}
\hline Sample No & $87 \mathrm{Sr} / 86 \mathrm{Sr}$ & $\mathrm{Rb}(\mathrm{ppm})$ & $\mathrm{Sr}(\mathrm{ppm})$ & $87 \mathrm{Sr} / 86 \mathrm{Sr}(\mathrm{i})$ & $143 \mathrm{Nd} / 144 \mathrm{Nd}$ & $\mathrm{Sm}(\mathrm{ppm})$ & Nd (ppm) & $143 \mathrm{Nd} / 144 \mathrm{Nd}(\mathrm{i})$ & enD \\
\hline GOTK1 & 0.70790 & 130 & 621 & 0.70773 & 0.51244 & 7.5 & 28.9 & 0.51241 & -3.9 \\
\hline GOTK2 & 0.70789 & 117 & 602 & 0.70787 & 0.51245 & 5.8 & 35.6 & 0.51243 & -3.5 \\
\hline GOTK9 & 0.70734 & 94 & 467 & 0.70718 & 0.51246 & 5.0 & 29.3 & 0.51245 & -3.2 \\
\hline GOTK11 & 0.70799 & 118 & 384 & 0.70774 & 0.51243 & 4.9 & 30.3 & 0.51242 & -3.8 \\
\hline GOTK6 & 0.70887 & 120 & 308 & 0.70855 & 0.51237 & 4.6 & 26.4 & 0.51236 & -5.0 \\
\hline GOTK12 & 0.70775 & 113 & 724 & 0.70762 & 0.51230 & 8.5 & 47.6 & 0.51228 & -6.5 \\
\hline GOTK13 & 0.70801 & 104 & 415 & 0.70781 & 0.51242 & 4.7 & 28.4 & 0.51241 & -4.0 \\
\hline GOTK14 & 0.70841 & 86 & 333 & 0.70820 & 0.51245 & 4.9 & 26.0 & 0.51244 & -3.4 \\
\hline GOTK15 & 0.70957 & 119 & 294 & 0.70923 & 0.51235 & 4.5 & 26.4 & 0.51234 & -5.4 \\
\hline GOTK7 & 0.70805 & 105 & 369 & 0.70782 & 0.51243 & 4.5 & 27.5 & 0.51241 & -3.9 \\
\hline GOTK16 & 0.70794 & 108 & 418 & 0.70773 & 0.51242 & 5.7 & 34.8 & 0.51241 & -4.0 \\
\hline GOTK3 & 0.70735 & 118 & 591 & 0.70718 & 0.51245 & 3.9 & 27.0 & 0.51244 & -3.4 \\
\hline
\end{tabular}

Note: enD values are calculated relative to CHUR with present day values of $\left({ }^{143} \mathrm{Nd} /{ }^{144} \mathrm{Nd}\right)_{\text {chur }}=0.512638$ and ${ }^{147} \mathrm{Sm} /{ }^{144} \mathrm{Nd}=0.1967$, $\left.\lambda^{147} \mathrm{Sm}=6.54 \times 10^{-12} \mathrm{enD}:\left(\left({ }^{143} \mathrm{Nd} /{ }^{144} \mathrm{Nd}\right)_{\text {sample }} /\left({ }^{143} \mathrm{Nd} /{ }^{144} \mathrm{Nd}\right)_{\mathrm{CHUR}}-1\right)\right)^{*} 10.000$ (Wasserburg et al. 1981; Jacobsen and Wasserburg 1984). Initial values are calculated for an assumed age of $20 \mathrm{Ma}$ 
Table 2 Isotope data $(\mathrm{Pb})$ of magmatic whole rock samples from the Pinarbaşı intrusion

\begin{tabular}{|c|c|c|c|c|c|c|c|c|c|}
\hline Sample No & $206 / 204 \mathrm{~Pb}$ & $207 / 204 \mathrm{~Pb}$ & $208 / 204 \mathrm{~Pb}$ & $\mathrm{~Pb}$ ppm & U ppm & Th ppm & $206 \mathrm{~Pb} / \mathrm{Pb} 204(\mathrm{i})$ & $207 \mathrm{~Pb} / 204 \mathrm{~Pb}(\mathrm{i})$ & $208 \mathrm{~Pb} / 204 \mathrm{~Pb}(\mathrm{i})$ \\
\hline GOTK01 & 18.992 & 15.719 & 39.126 & 40.5 & 9.2 & 26.4 & 18.946 & 15.717 & 39.083 \\
\hline GOTK02 & 19.001 & 15.723 & 39.139 & 41.5 & 7.0 & 30.0 & 18.967 & 15.721 & 39.091 \\
\hline GOTK09 & 18.961 & 15.719 & 39.122 & 19.6 & 2.5 & 12.5 & 18.935 & 15.718 & 39.080 \\
\hline GOTK12 & 19.044 & 15.725 & 39.124 & 49.6 & 5.7 & 27.3 & 19.021 & 15.724 & 39.088 \\
\hline GOTK14 & 18.961 & 15.717 & 39.121 & 17.3 & 2.2 & 13.2 & 18.935 & 15.716 & 39.070 \\
\hline GOTK06 & 18.975 & 15.721 & 39.124 & 34.0 & 4.4 & 22.5 & 18.949 & 15.720 & 39.080 \\
\hline GOTK07 & 18.977 & 15.721 & 39.138 & 34.1 & 5.0 & 28.7 & 18.948 & 15.720 & 39.082 \\
\hline GOTK11 & 18.969 & 15.718 & 39.129 & 27.8 & 3.7 & 25.5 & 18.942 & 15.717 & 39.068 \\
\hline GOTK13 & 18.984 & 15.721 & 39.139 & 28.1 & 4.9 & 28.2 & 18.949 & 15.719 & 39.073 \\
\hline GOTK15 & 18.976 & 15.719 & 39.111 & 37.2 & 4.6 & 17.4 & 18.951 & 15.718 & 39.080 \\
\hline GOTK16 & 18.959 & 15.722 & 39.116 & 39.8 & 4.6 & 28.1 & 18.936 & 15.721 & 39.069 \\
\hline GOTK3 & 18.976 & 15.719 & 39.111 & 43.0 & 8.0 & 30.2 & 18.939 & 15.717 & 39.065 \\
\hline
\end{tabular}
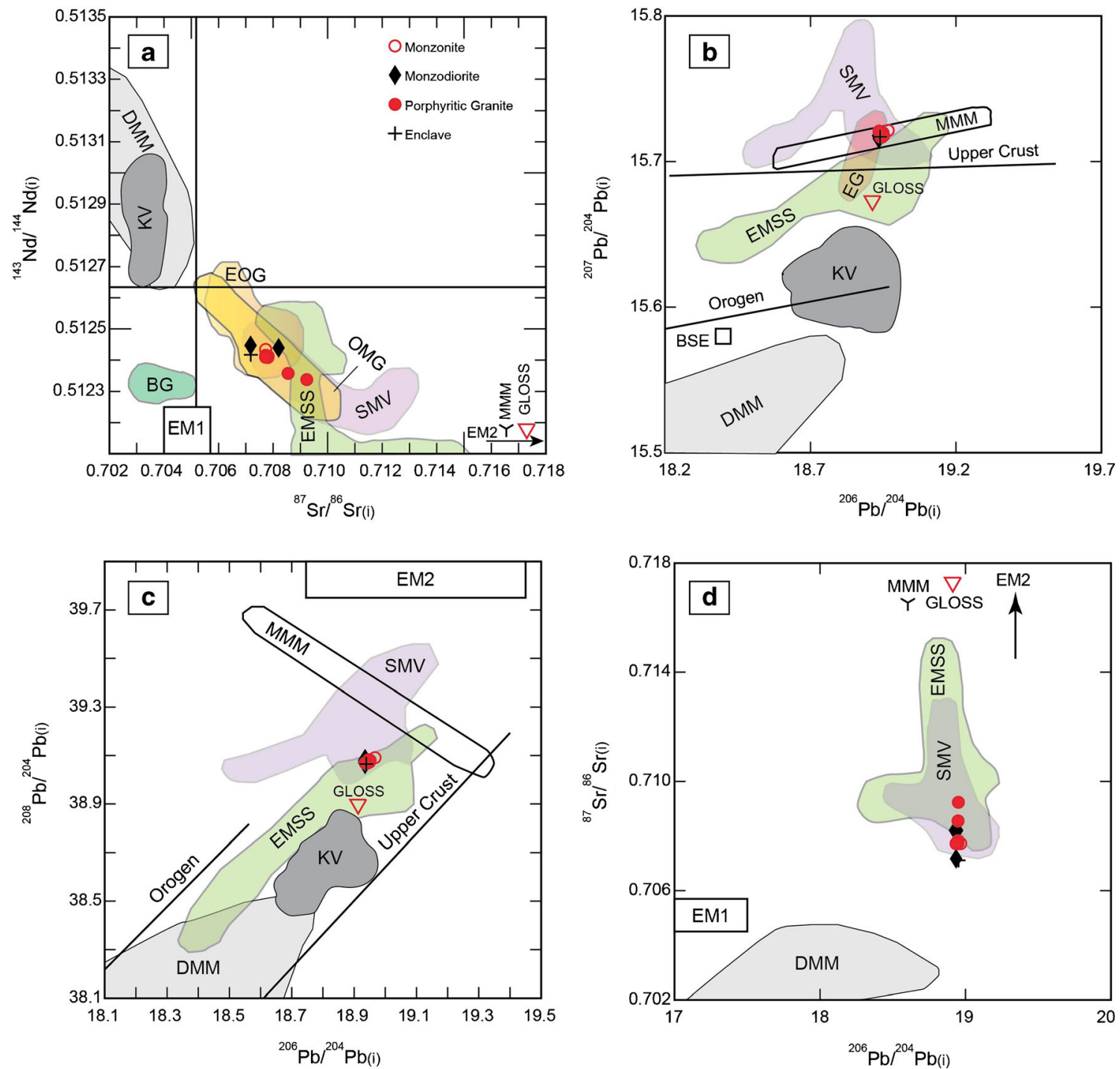

Fig. $8 \mathrm{~Pb}, \mathrm{Nd}$ and $\mathrm{Sr}$ isotopic compositions of rock samples from the Pınarbaș1 pluton compared with various potential source reservoirs and rocks. The composition of present-day CHUR was calculated for $20 \mathrm{Ma}$. Lead isotope Upper Crust and Orogen curves from Zartman and Doe (1981). BG: Baklan Granitoid (Aydoğan et al. 2008); BSE: Bulk silicate earth from Zindler and Hart (1986); DMM: Depleted MORB; EM1: Enriched mantle I; EM2: Enriched mantle II; EMSS: Eastern Mediterranean Sea Sediments (Klaver et al. 2015); EOG: Eocene

Granitoids (Altunkaynak et al. 2012b); GLOSS: Global Subducted Sediments (Plank and Langmuir 1998); KV: Kula volcanic rocks (Güleç 1991; Alici et al. 2002; Innocenti et al. 2005; Dilek and Altunkaynak 2010; Chakrabarti et al. 2012); MMM: Menderes Massif metamorphic rocks (Çoban et al. 2012); OMG: Oligo-Miocene Granitoids (Altunkaynak et al. 2012a); SMV: Simav volcanicsubvolcanic rocks (Coban et al. 2012) 
and basement metamorphic rocks (MMM, higher radiogenic $\mathrm{Sr}$ reservoirs) with nearly constant ${ }^{206} \mathrm{~Pb} /{ }^{204} \mathrm{~Pb}_{(\mathrm{i})}$ ratios.

\section{Molybdenite Re-Os geochronology}

The Re-Os age results for two molybdenite samples are presented in Table 3 and the analytical techniques are summarized in Online Resource 1. Two molybdenite samples were selected from an outcrop (OKY-3-4) and a drill core (GOP-19 m) from the Pınarbaşı prospect. Sample OKY-3-4 was collected from a molybdenite-hematite bearing silicified zone (Fig. 4d), and sample GOP-19 $\mathrm{m}$ was taken from a $0.5-1 \mathrm{~cm}$ thick quartz-molybdenite-pyrite-chalcopyrite vein crosscutting a highly sericitized porphyritic granite (Fig. 4e). The total Re concentrations of the molybdenite samples are 950 and 1036 ppm and ${ }^{187}$ Os concentrations are 181 and 199 ppb. Samples OKY-3-4 and GOP-19 m yield Re-Os ages of $18.3 \pm 0.1 \mathrm{Ma}$ and $18.2 \pm 0.1 \mathrm{Ma}$, respectively (Table 3 ).

\section{Discussion}

\section{Shallow-level magmatic processes}

Decreasing $\mathrm{CaO}, \mathrm{Fe}_{2} \mathrm{O}_{3}, \mathrm{TiO}_{2}, \mathrm{P}_{2} \mathrm{O}_{5}$, and $\mathrm{V}$ trends with increasing $\mathrm{SiO}_{2}$ are consistent with pyroxene, apatite, and $\mathrm{Fe}-\mathrm{Ti}$ oxide fractionation during the evolution of the magmas of the Pinarbaş1 intrusion (see Online Resource 4), and the fractionated LREE element patterns and slightly negative Eu anomalies indicate plagioclase fractionation during the evolution of the felsic pluton. In addition, the negative correlation of $\mathrm{Dy} / \mathrm{Yb}$ with $\mathrm{SiO}_{2}$ (Fig. 9a), the positively correlated $\mathrm{Zr} / \mathrm{Sm}$ ratio and $\mathrm{SiO}_{2}$ contents, as well as the slightly upward concave trend from MREEs to HREEs (Figs. 7b and 9b) suggest low-pressure amphibole fractionation in the presence of plagioclase. These fractionation trends, coupled with the negative correlation of $\mathrm{Al}_{2} \mathrm{O}_{3}, \mathrm{Na}_{2} \mathrm{O}$, and $\mathrm{Sr}$ with $\mathrm{SiO}_{2}$ are consistent with combined amphibole, plagioclase, and pyroxene fractionation at low pressure, and the absence of high-pressure garnet fractionation and garnetbearing residue in the source (see Online Resource 4; Macpherson et al. 2006; Davidson et al. 2007, 2013; AlonsoPerez et al. 2009; Hora et al. 2009).
The Pınarbaşı samples are characterized by upper continental crust-like lithogeochemical compositions (Fig. 7a-b). On the ${ }^{206} \mathrm{~Pb} /{ }^{204} \mathrm{~Pb}_{(\mathrm{i})}$ vs ${ }^{207} \mathrm{~Pb} /{ }^{206} \mathrm{~Pb}_{(\mathrm{i})}$ diagram (Fig. 8b), all Pınarbaş1 samples plot above the Upper Crustal curve (Zartman and Doe 1981) and overlap with the basement metamorphic rocks. However, the $\mathrm{Sr}$ and $\mathrm{Nd}$ isotopic compositions together with $\mathrm{A} / \mathrm{CNK}$ ratios of 3 to 2 and $\mathrm{Mg \#}$ values of 30-47 for metamorphic basement (Dilek et al. 2009) are different from those of the metamorphic basement rocks of the region. The high ${ }^{87} \mathrm{Sr} /{ }^{86} \mathrm{Sr}_{(\mathrm{i})}$ ratios of the evolved samples of porphyritic granite (Fig. 8a; Table 1) are consistent with upper crustal assimilation concomitant with fractional crystallization (DePaolo 1981). The 1/Sr vs. ${ }^{87} \mathrm{Sr} /{ }^{86} \mathrm{Sr}_{(\mathrm{i})}$ and $\mathrm{SiO}_{2}$ vs. ${ }^{208} \mathrm{~Pb} /{ }^{204} \mathrm{~Pb}_{(\mathrm{i})}$ plots also show that the porphyritic granite, which crosscuts the Pınarbașı monzonite, reflects shallow-level crustal assimilation during fractionation (Fig. 9c-d). On the ${ }^{206} \mathrm{~Pb} /{ }^{204} \mathrm{~Pb}_{(\mathrm{i})} \mathrm{vs}{ }^{87} \mathrm{Sr} /{ }^{86} \mathrm{Sr}_{(\mathrm{i})}$ plot (Fig. 8d), the Pınarbașı samples display a trend with variable ${ }^{87} \mathrm{Sr} /{ }^{86} \mathrm{Sr}_{\mathrm{i}}$ ratios for nearly constant ${ }^{206} \mathrm{~Pb} /{ }^{204} \mathrm{~Pb}_{(\mathrm{i})}$ ratios.

However, several compositional characteristics are attributed to source-inheritance rather than to shallow-level crustal assimilation and fractionation only. They include (1) the least radiogenic Sr compositions (Fig. 8d), (2) a low ${ }^{208} \mathrm{~Pb} /{ }^{204} \mathrm{~Pb}_{(\mathrm{i})}$ ratio distinct with respect to the metamorphic basement (MMM in Fig. 8c), (3) samples with the most radiogenic $\mathrm{Nd}$ isotopic compositions (Fig. 8a), and (4) enriched $\mathrm{U}$ and $\mathrm{Pb}$ contents of the Pınarbaș1 samples with respect to those of the metamorphic basement (MMM in Fig. 7a). In summary, trace element patterns and $\mathrm{Pb}$ isotope ratios indicate that the magmas at the origin of the Pınarbaşı intrusion have assimilated middle to upper crustal materials.

\section{Source of magma}

In addition to fractional crystallization and assimilation (AFC) during evolution of the Pınarbaşı magmas, there is geochemical and isotopic evidence for open-system evolution, including partial melting, crust-mantle interaction, and enriched mantle contributions. Partial melting of hydrous calc-alkaline to high-K calc-alkaline, and basaltic to intermediate metamorphic rocks can produce moderate to mildly peraluminous high-K, I-type granitoids (Rapp et al. 1991; Roberts and Clemens 1993; Rudnick and Gao 2003). This can explain the mildly

Table 3 Re-Os data for molybdenite from the Pınarbaşı prospect

\begin{tabular}{|c|c|c|c|c|c|c|}
\hline Sample No & wt (g) & $\operatorname{Re}(p p m) \pm 2 \sigma$ & ${ }^{187} \operatorname{Re}(\mathrm{ppm}) \pm 2 \sigma$ & ${ }^{187} \mathrm{Os}(\mathrm{ppb}) \pm 2 \sigma$ & Age $(\mathrm{Ma}) \pm 2 \sigma(1)$ & Age $(\mathrm{Ma}) \pm 2 \sigma(2)$ \\
\hline GOP-19 m & 0.01047 & $950.3 \pm 4.7$ & $597.3 \pm 3.0$ & $181.2 \pm 0.8$ & $18.21 \pm 0.07$ & $18.21 \pm 0.09$ \\
\hline OKY3-4 & 0.01014 & $1035.5 \pm 5.2$ & $650.8 \pm 3.3$ & $198.5 \pm 0.9$ & $18.30 \pm 0.07$ & $18.30 \pm 0.09$ \\
\hline
\end{tabular}

Re-Os dates are calculated using Re decay constants from Smoliar et al. (1996)

(1) age uncertainty includes all sources of analytical uncertainty

(2) age uncertainty includes all sources of analytical uncertainty and that of the decay constant 

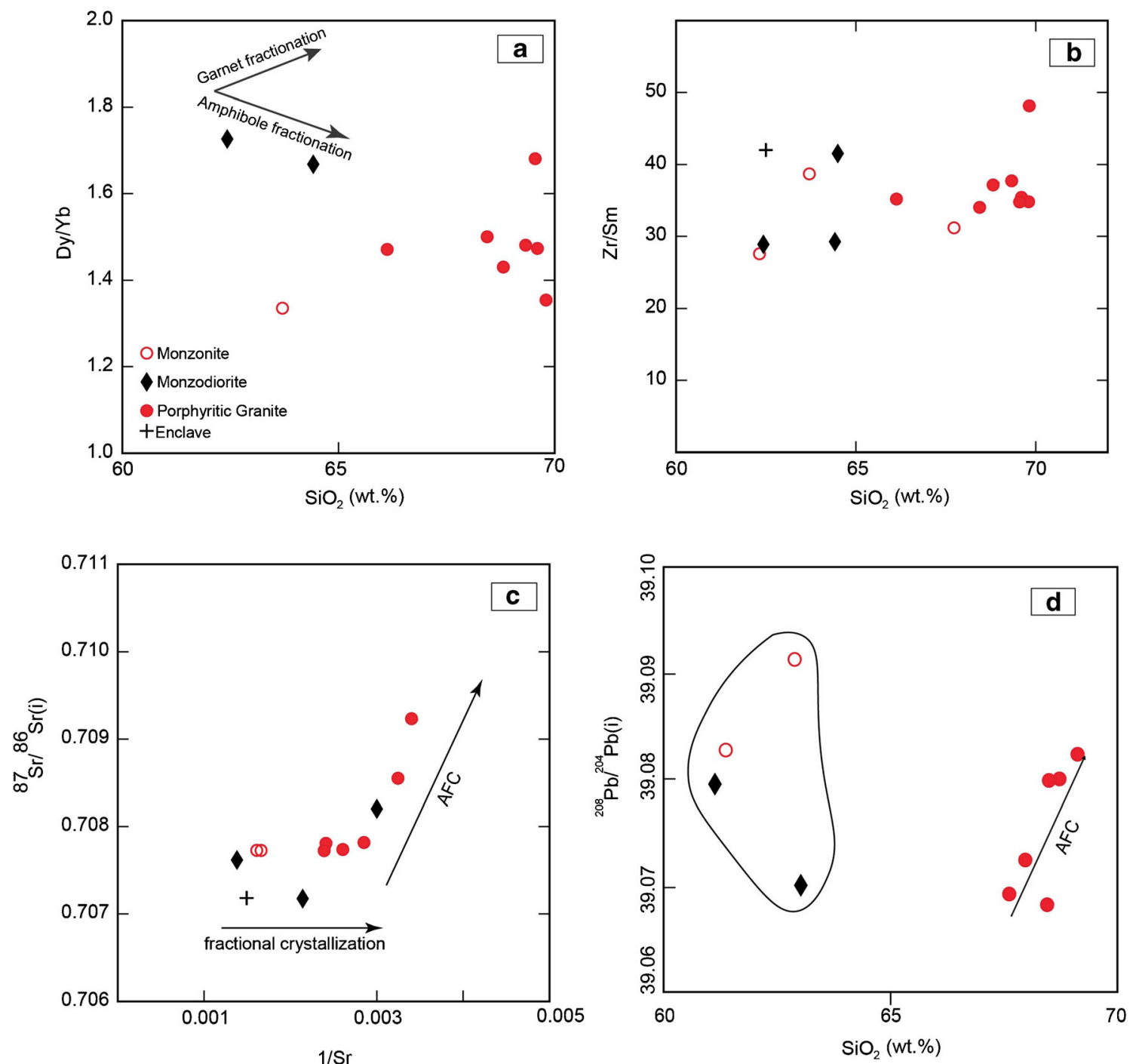

Fig. 9 Trace element and isotope variation diagrams for magmatic rocks from the Pınarbası pluton: a $\mathrm{Dy} / \mathrm{Yb}$ versus $\mathrm{SiO} 2$ (wt.\%), b $\mathrm{Zr} / \mathrm{Sm}$ versus $\mathrm{SiO} 2$ (wt.\%), c initial ${ }^{87} \mathrm{Sr} /{ }^{86} \mathrm{Sr}$ versus $1 / \mathrm{Sr}(1 / \mathrm{ppm}), \mathbf{d ~ S i O} \mathrm{S}_{2}$ (wt.\%) versus

peraluminous composition of the Oligo-Miocene granitic rocks in western Anatolia (Fig. 6d), and they are distinct with respect to the composition of metagraywacke and metapelite partial melts (Fig. 10a).

The high-K and LILE-enriched (e.g., Ba, Sr) magmas can also be produced from the influx of a LILE- and LREEenriched- mantle melt at the base of the lower crust, and this source could be produced by small to moderate degrees $(\leq 20 \%)$ of partial melting of phlogopite-clinopyroxene-amphibole-bearing metasomatised lithospheric mantle due to heating by asthenospheric upwelling (Lloyd et al. 1985; Foley 1992; Conticelli et al. 2002; Grove et al. 2003; Condamine and Médard 2014). On the La/Yb vs La diagram (Fig. 10b), the Pınarbași samples scatter between the partial melting and fractional crystallization lines, suggesting partial melting of a lithospheric mantle source contemporaneously with fractionation, and the highly variable $\mathrm{Nb} / \mathrm{Ta}$ ratio of the monzonitic and granitic initial ${ }^{208} \mathrm{~Pb} /{ }^{204} \mathrm{~Pb}$ isotope ratios (AFC: assimilation + fractional crystallization trend from DePaolo 1981)

samples between 7.9 and 34 ( 11-12 for crust, and 17.5 for mantle; Green 1995) indicate fractional crystallization and low degrees of partial melting. In addition, the high $\mathrm{Rb} / \mathrm{Sr}(0.2-0.4)$ and highly variable $\mathrm{Ba} / \mathrm{Rb}$ (7.5-18.6) ratios of the Pınarbaşı samples are consistent with partial melting of a residual hydrous phlogopite-amphibole- enriched mantle source (see Online Resource 2; Furman and Graham 1999; Guo et al. 2013). The low $\mathrm{Sm} / \mathrm{Yb}$ ratio below 3 of the Pınarbaşı granitic and monzonitic samples (Fig. 10c) suggests a residue above the garnet stability field at 35-40 km (Kay and Mpodozis 2001). The position of all samples in the mantle-crust interaction field in the $\mathrm{Nb}-\mathrm{Y}-\mathrm{Ga} * 3$ ternary diagram of Eby (1992) (Fig. 10d) is consistent with phlogopite-amphibole-pyroxene-bearing lithospheric mantle-lower crust interactions.

Based on our geochemical data, the absence of residual garnet in the magma source reflects a relatively thin crust in mid-western Anatolia since at least the Oligo-Miocene. 
Geophysical data document a present-day average crustal thickness of 25 to $33 \mathrm{~km}$ in western Anatolia, and an average crustal thickness of $40 \mathrm{~km}$ during the early Miocene (Dhont et al. 2006; Mutlu and Karabulut 2011; Karabulut et al. 2013). Consequently, our results coupled with the crustal thickness of western Anatolia allow us to conclude that enriched subcontinental lithospheric mantle interacted with the lower crust and generated the parental magmas of the Oligo-Miocene granitic intrusions at relatively low pressure $(35-40 \mathrm{~km})$.

\section{Post-subduction tracers}

Enrichment of LILEs (e.g., $\mathrm{Ba}, \mathrm{Rb}, \mathrm{Sr}$ ), $\mathrm{U}$ and $\mathrm{Pb}$, depletion of $\mathrm{Nb}$ and $\mathrm{Ta}$, and high $\mathrm{Ba} / \mathrm{La}, \mathrm{Ba} / \mathrm{Th}, \mathrm{Rb} / \mathrm{Y}, \mathrm{Sr} / \mathrm{Th}$ and $\mathrm{Sr} / \mathrm{Nd}$ ratios are attributed to fluid addition to the mantle wedge from dehydration of a subducted slab (Pearce and Peate 1995; Keppler 1996). By contrast, enrichment of Th, $\mathrm{La}$, and $\mathrm{Nb}$ are attributed to metasomatism of the mantle by melting of a subducted sedimentary component (Tatsumi et al. 1986; Plank
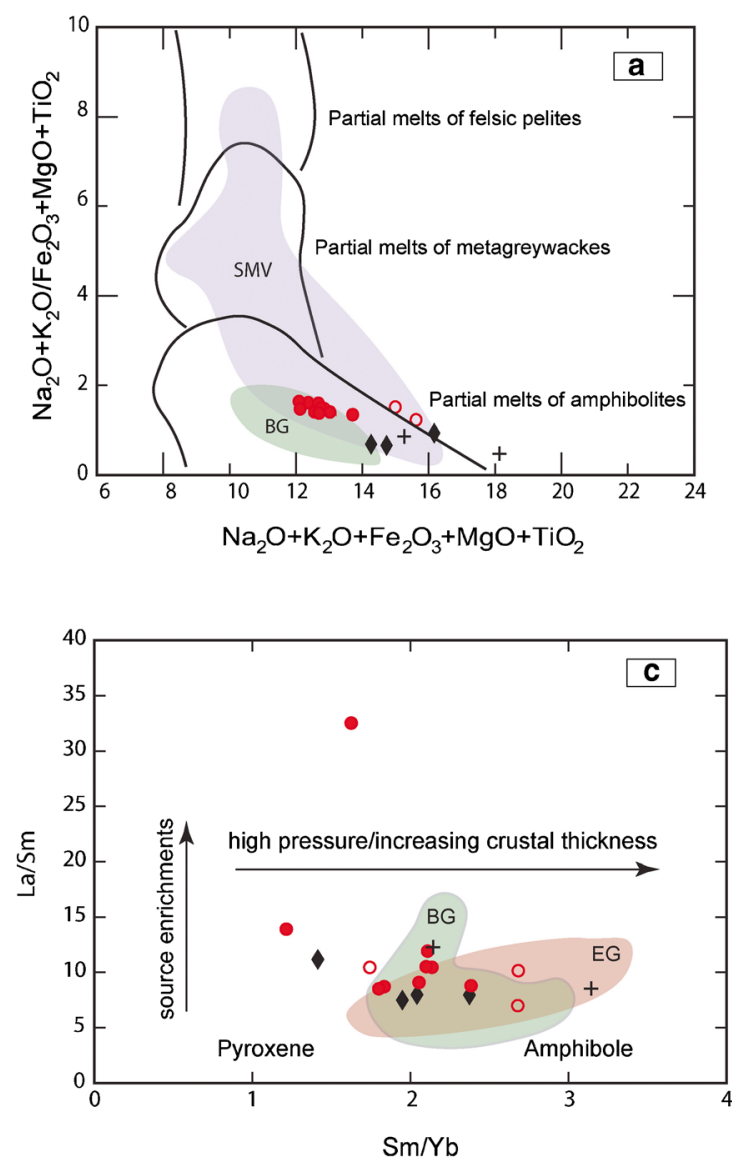

Fig. 10 a $\left(\mathrm{Na}_{2} \mathrm{O}+\mathrm{K}_{2} \mathrm{O}+\mathrm{Fe}_{2} \mathrm{O}_{3}+\mathrm{MgO}+\mathrm{TiO}_{2}\right)$ versus $\left.\mathrm{Na}_{2} \mathrm{O}+\mathrm{K}_{2} \mathrm{O}\right) /$ $\left(\mathrm{Fe}_{2} \mathrm{O}_{3}+\mathrm{MgO}+\mathrm{TiO}_{2}\right)$ discrimination plot for granite melt sources (Patiño Douce 1999), b La (ppm) versus La/Yb diagram, with partial melting and fractional crystallization trends from Thirlwall et al. (Thirwall et al. 1994), c La/Sm versus $\mathrm{Sm} / \mathrm{Yb}$ diagram, with pressure- and Langmuir 1993; Brenan et al. 1995; Pearce and Peate 1995; Plank 2005).

All samples of the Pınarbaşı intrusion, together with the OligoMiocene granitic rocks of the western Aegean, exhibit variable $\mathrm{Th} / \mathrm{Yb}$ ratios for nearly constant $\mathrm{Ta} / \mathrm{Yb}$ ratios (Fig. 11a), and reflect a subduction-related environment. The wide range of $\mathrm{Ba}$ (666-2100 ppm), Sr (333-621 ppm) contents and high $\mathrm{Ba} / \mathrm{La}$ (17.7-42.6) ratios of the Pınarbaşı samples are consistent with addition of aqueous fluids derived from the mantle wedge to the sub-lithospheric mantle. A narrow range of $\mathrm{Nb} / \mathrm{Y}$ ratio with highly variable Ba contents could also be attributed to slab-derived fluid enrichment (Fig. 11b). On the other hand, the relatively high $\mathrm{Th} / \mathrm{La}(0.33-0.73), \mathrm{Th} / \mathrm{Nb}(1.0-2.3), \mathrm{Zr} / \mathrm{Hf}(33.4-41.9, \mathrm{Zr} /$ $\mathrm{Hf}=\sim 39.6$ for EMSS) and a wide range of $\mathrm{Th} / \mathrm{Yb}$ ratios $(5.2-$ 13.6; excluding the high $\mathrm{Th} / \mathrm{Yb}$ ratio of 31 of sample GOTK-18), as well as the low $\mathrm{Ce} / \mathrm{Pb}$ ratios $(1.35-3.84 ; \mathrm{Ce} / \mathrm{Pb}=\sim 3.98$ for EMSS and $\mathrm{Ce} / \mathrm{Pb}=2-3$ for terrigenous sediments; Lan et al. 1990; Klaver et al. 2015), with small negative Ce anomalies of Pınarbaşı granitic and monzonitic rocks (Fig. 7a) could be
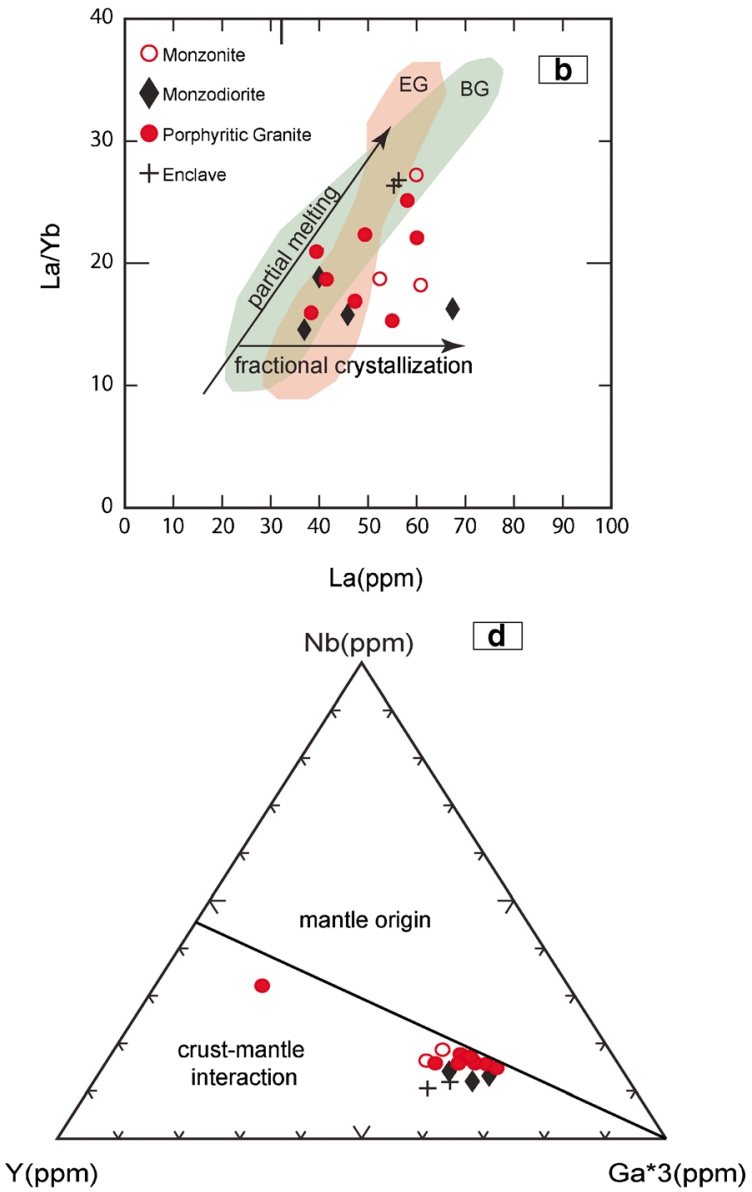

dependent pyroxene and amphibole stabilities from Kay and Mpodozis (2001), d Nb-Y-Ga*3 granite classification diagram after Eby (1992). BG: Baklan granitoid (Aydoğan et al. 2008); EG: Eğrigöz granitoid (Altunkaynak et al. 2012a, Coban et al. 2012); SMV: Simav volcanicsubvolcanic rocks (Çoban et al. 2012) 
indicative of a sedimentary component mixed with an enriched mantle source. In the $\mathrm{Nb} / \mathrm{Y}$ vs. Rb/Y plot (Fig. 11c), the Pınarbaș1 samples exhibit a trend between melt-related enrichment and slabderived fluid enrichment array lines. These metasomatic agents are further documented by the oblique trend between fluid- and melt-related enrichment trend lines on the $\mathrm{Th} / \mathrm{Nb}$ vs. $\mathrm{Ba} / \mathrm{Th}$ plot (Fig. 11d) and also on the $\mathrm{Ba} / \mathrm{La}$ vs $\mathrm{Th} / \mathrm{Yb}$ plot (Fig. 11e). They have higher $\mathrm{Ba} / \mathrm{Nb}$ and $\mathrm{Th} / \mathrm{Nb}$ ratios than the EMSS and on the $\mathrm{Th} / \mathrm{Nb}$ vs. $\mathrm{Ba} / \mathrm{Nb}$ diagram (Fig. 11f), they lie along both the sediment melting and aqueous fluid trend lines. It is known that wet sediment melting can only occur at depths greater than $100 \mathrm{~km}$ under relatively high temperatures $\left(\sim 800^{\circ} \mathrm{C}\right)$ and the increased $\mathrm{K}$, Th, Ta, and $\mathrm{Nb}$ concentrations in arc-suites are attributed to the distance from the subduction trenches, reflecting the heterogeneous mantle sources that change from subductionrelated to within-plate away from the trench and the low degree of partial melting in the back-arc setting also leads to enrichment in incompatible elements (Barragan et al. 1998; Aizawa et al. 1999; Duggen et al. 2007; Richards 2011; Müller and Groves 2016). Therefore, the enrichment processes can be linked with magmatism related to back-arc opening in the region as a consequence of hot asthenospheric upwelling attributed either to slab rollback and subsequent slab tear processes (Spakman et al. 1988; Jolivet and Brun 2010; van Hinsbergen 2010; Erkül et al. 2013; Ersoy and Palmer 2013; Jolivet et al. 2013, 2015) or lithospheric delamination and convective thinning of the lithospheric mantle (Dilek et al. 2009; Altunkaynak et al. 2012a).

\section{Age of Mo-Cu mineralization}

The early Miocene crystallization ages of molybdenite from the stockwork veins $(18.3 \pm 0.1 \mathrm{Ma}$ and $18.2 \pm 0.1 \mathrm{Ma})$ coincide with the crystallization and cooling ages of the granitic rocks of the Oligo-Miocene magmatic pulse in western Anatolia (Fig. 12; 24.0 and 18 Ma; Isik et al. 2004; Ring and Collins 2005; Aydoğan et al. 2008; Hasözbek et al. 2010; Altunkaynak et al. 2012a). This indicates a very close relationship of the mineralization event with the latest magmatic differentiation, crystallization and subsequent cooling stages. In addition, the early Miocene age of the Mo-Cu mineralization at Pınarbașı shows that metal enrichment was closely related to early Miocene post-orogenic magmatism (Fig. 12).

\section{Origin of metals in the porphyry-style Mo-Cu Pınarbaşı prospect}

The trace element data and the $\mathrm{Sr}, \mathrm{Nd}$, and $\mathrm{Pb}$ isotopic compositions of the Pınarbaș intrusive rocks suggest that the $\mathrm{Mo}-\mathrm{Cu}$ bearing monzonitic and granitic rocks were derived from a melt that was produced by interaction of an enriched, metasomatised lithospheric mantle and a lower crust at a depth of $35-40 \mathrm{~km}$ during the Oligo-Miocene. The enriched melt influx from the metasomatised lithospheric mantle into the lower crust resulted in partial melting of the lower crust at the lithospheric mantle-lower crust interface. Lithospheric mantle interaction with the lower crust likely increased through time, and lithospheric influx during the mid to late Miocene probably resulted in thickening of the lower crust in western Anatolia (see also discussion by Ersoy et al. 2010). This is consistent with the evolution of OligoMiocene high-K calc-alkaline to middle Miocene shoshonitic magmatism in the region interpreted as deep partial melting (Thorpe and Francis 1979). It is also in line with the formation of an amphibole-garnet-bearing residual source during early to middle Miocene magmatism (e.g., Ersoy et al. 2010; Çoban et al. 2012; Karaoğlu and Helvaci 2014).

Continuous partial melting of chalcophile and siderophile element-enriched lower crustal amphibolitic cumulates and subcontinental lithospheric mantle can produce $\mathrm{H}_{2} \mathrm{O}$-bearing, volatile-rich and fertile melts, which are the source of metals of porphyry Au-Cu deposits in post-collisional extensional settings (Richards 2009; Hou et al. 2011; Richards and Mumin 2013; Hou and Zhang 2014; Müller and Groves 2016). The crustal or mantle origin of the Mo-enrichment in porphyry systems is still debated (Audetat 2010; Richards 2011). Pettke et al. (2010) advocated melting for sub-continental metasomatised old mantle as the source of Mo for giant porphyry Mo-rich systems in the Western U.S.A., and Mao et al. (2011) suggested that repeated melting of the lower crust can explain Mo-enrichment in back-arc extensional settings during post-collisional magmatism. Molybdenum is enriched in reduced sediments and is also immobile in low-temperature fluids (Crusius et al. 1996). Chondritic to super-chondritic ratios of $\mathrm{Zr} / \mathrm{Hf}$ (33-42) and Hf/Sm (0.75-1.04) of the Pınarbaș1 intrusion reveal a terrigenous character of the subducted crustal material (chondritic value of Hf/Sm: $0.75 ; \mathrm{Zr}$ / Hf: 35-40, Patchett et al. 2004, Claiborne et al. 2006). Therefore, our study reveals that melting of terrigenous sediments can also supply Mo to an enriched lithospheric mantle source in a back-arc setting. In light of these studies, it is concluded that a lithospheric mantle metasomatised by fluids and subducted sediments, interacting at relatively low-pressure conditions (depths of 35$40 \mathrm{~km}$ ) with lower crust could explain the $\mathrm{Mo}-\mathrm{Cu}$ enrichment of the Pınarbaşı intrusion during back-arc magmatism (Fig. 12). The over-thickened sub-continental lithospheric mantle during early to late Miocene could have created the adequate environment for the evolution of larger scale $\mathrm{Au} \pm \mathrm{Cu} \pm$ Mo-rich deposits in western Anatolia (e.g., middle Miocene Uşak-Afyon-Konya district, Kușçu et al. 2011; Rabayrol et al. 2014), because of continuous melting of chalcophile and siderophile elementenriched amphibolite cumulates in the thickened lower crust and the enriched lithospheric mantle.

\section{Tectonic setting, exhumation and epithermal overprint of the porphyry Mo-Cu Pınarbașı prospect}

Extensional tectonics favors the migration of highly oxidized, $\mathrm{Cu}-, \mathrm{Au}-$ and Mo-rich melts derived from the mantle and the 

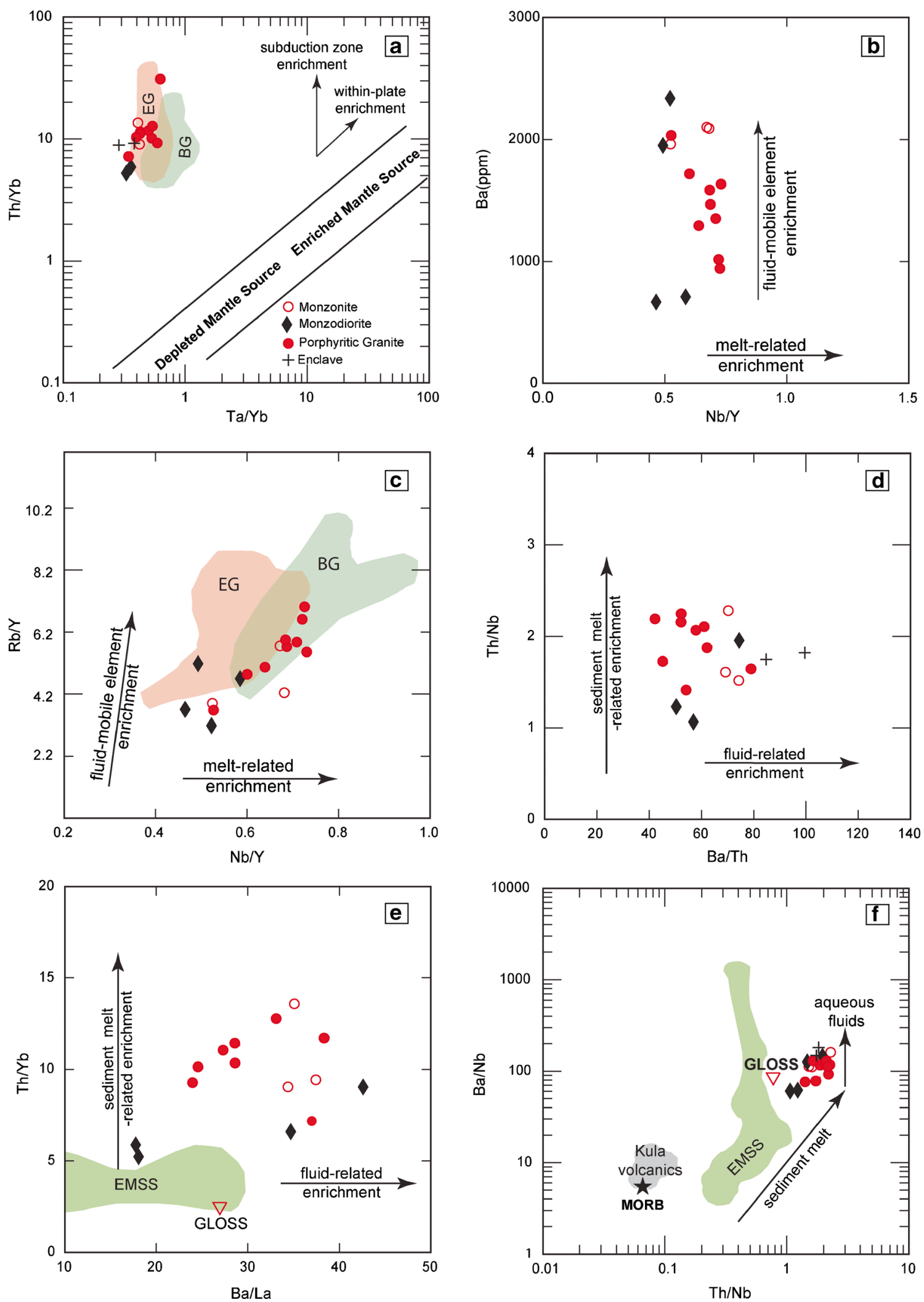

Fig. 11 a $\mathrm{Ta} / \mathrm{Yb}$ versus $\mathrm{Th} / \mathrm{Yb}$ discrimination diagram after Pearce (1983), b Nb/Yb versus $\mathrm{Ba}$ (ppm) diagram, $\mathbf{c} \mathrm{Nb} / \mathrm{Y}$ versus $\mathrm{Rb} / \mathrm{Y}$ diagram, fluid- and melt-related enrichment trends from Zhao and Zhou (2007), $\mathbf{d ~ B a / T h}$ versus $\mathrm{Th} / \mathrm{Nb}$ diagram, e $\mathrm{Ba} / \mathrm{La}$ versus $\mathrm{Th} / \mathrm{Yb}$ diagram, $\mathbf{f}$ $\mathrm{Th} / \mathrm{Nb}$ versus $\mathrm{Ba} / \mathrm{Nb}$ diagram with sediment melt and aqueous fluids

trends from Ribeiro et al. (2013). MORB data from Hofmann (1997). BG: Baklan granitoid (Aydoğan et al. 2008); EG: Eğrigöz granitoid (Altunkaynak et al. 2012a, Çoban et al. 2012); EMSS: Eastern Mediterranean Sea Sediments (Klaver et al. 2015); GLOSS: Global Subducted Sediments (Plank and Langmuir 1998) 


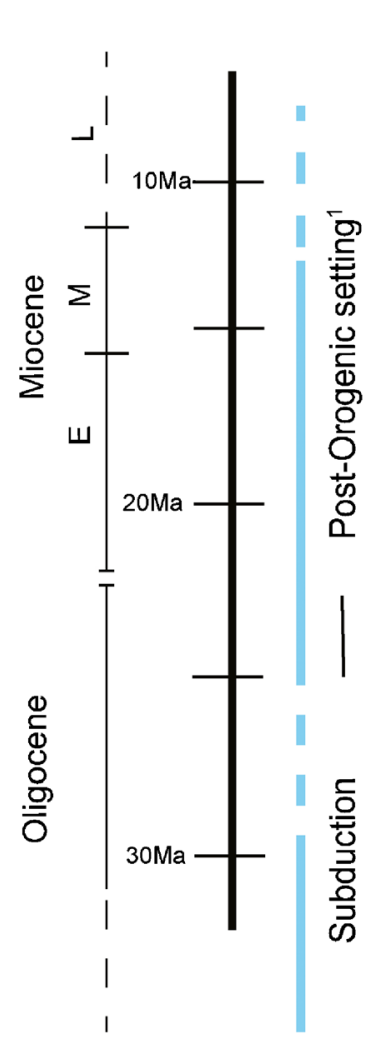

Fig. 12 Summary of major tectonic and magmatic events within western Anatolia from Oligocene to Miocene. 1: Jolivet and Brun (2010), van Hinsbergen (2010), Jolivet et al. (2015); 2-3: Spakman et al. (1988), Jolivet and Brun (2010), van Hinsbergen (2010), Erkül et al. (2013), Ersoy and Palmer (2013), Jolivet et al. (2013, 2015); 4: Yilmaz (1989), Bozkurt et al. (1993), Hetzel et al. (1995), Bozkurt and Park (1997), Ring et al. (1999, 2010), Koçyiğit et al. (2000), Whitney and Bozkurt (2002),

lower crust into upper crustal levels (Vigneresse 2007). The orebearing melt at the origin of the Pınarbaşı intrusion could have rapidly ascended to mid-crustal levels with crustal assimilation along trans-lithospheric faults activated during extension, and resulting in porphyry-style $\mathrm{Mo}-\mathrm{Cu}$ mineralization during the early Miocene (at $\sim 18 \mathrm{Ma}$ ) that is consistent with the differentiationcrystallization and cooling history of the Oligo-Miocene granites (24-18 Ma). The first, late Oligocene to early Miocene phase of extension in the region is mainly characterized by the development of low-angle shear zones and the subsequent emplacement and exhumation of granitic rocks along the ductile shear zones (Fig. 12). Hence, the Oligo-Miocene felsic intrusions are regarded as syn-extensional, that cooled rapidly along the footwall of detachment faults (Ring et al. 2003; Isik et al. 2004; Ring and Collins 2005; Dilek et al. 2009; Erkül 2010). The second, middle to late Miocene extension phase in the region is characterized by the development of high-angle normal faults forming graben structures in western Anatolia (Yilmaz 1989; Hetzel et al. 1995; Ring et al. 2003; Fig. 12). The high-angle normal faulting resulted in uplift of the graben shoulders, deep erosion and further exhumation along the detachment footwalls, as well as cataclastic deformation of the Oligo-Miocene granitic rocks

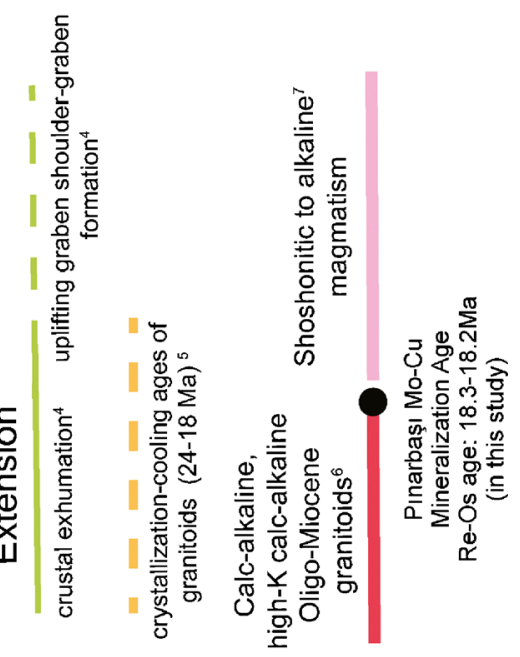

Bozkurt and Sözbilir (2004), Dilek et al. (2009), Agostini et al. (2010); 5: Isik et al. (2004), Ring and Collins (2005), Aydoğan et al. (Aydoğan et al. 2008), Hasözbek et al. (2010), Altunkaynak et al. (2012a); 6: Dilek et al. (2009), Altunkaynak et al. (2012a); 7: Doglioni et al. (2002), Innocentini et al. (Innocenti et al. 2005), Agostini et al. (2007, 2010), Helvaci et al. (2009), Karaoğlu et al. (2010), Ersoy and Palmer (2013)

(Yilmaz 1989; Dilek et al. 2009). Therefore, exhumation of the Mo-Cu-bearing Pınarbaşı intrusion, exposed in the northwestern shoulder of the Yenidoğmuş-YeniGediz graben, can be explained by uplift of the graben systems (Fig. 2, inset). Further uplift during the middle to late Miocene may have resulted in (1) removal of the shallow parts of the Pinarbaşı porphyry system in response to rapid erosion, (2) telescoping by $\mathrm{Sb} \pm \mathrm{Ag} \pm \mathrm{Au}$ lowsulfidation epithermal mineralization, and intense advanced argillic alteration at the Pınarbaşı prospect (Fig. 5e-f; Oygür and Erler 2000; Delibaș et al. 2012a). This is reminiscent of many porphyry systems in post-collisional extensional settings (e.g., Perello et al. 2001; Hou et al. 2009).

\section{Conclusions}

The high-K calc-alkaline Pınarbași intrusion shares many geochemical features with other calc-alkaline to high-K calc-alkaline Oligo-Miocene granitic rocks of western Anatolia. The monzonitic and granitic rocks of Pınarbașı were derived from interactions of an enriched lithospheric mantle and lower crust at depth of 35-40 km during Oligo-Miocene post-collisional 
magmatism. Trace-element ratios and distinct $\mathrm{Sr}, \mathrm{Nd}$, and $\mathrm{Pb}$ isotopic compositions of the Pınarbaşı intrusion suggest that two metasomatic agents could have been incorporated into the enriched mantle source reflecting post-orogenic magmatism. We conclude that the lithospheric mantle was metasomatised by fluids and subducted sediments, and its interaction with a lower crust at low-pressure conditions explains the $\mathrm{Mo}$ and $\mathrm{Cu}$ enrichment of the Pınarbașı intrusion during back-arc magmatism. The ore-bearing melt of the Pınarbaș1 intrusion could have rapidly ascended to mid-crustal levels, with only limited crustal assimilation along major trans-lithospheric faults as a result of the thinning of middle to upper crust during regional extension, and resulted in the development of porphyry-style mineralization during the early Miocene ( $18 \mathrm{Ma})$. The subsequent exhumation history of the Mo$\mathrm{Cu}$-bearing Pınarbaşı intrusion is attributed to regional-scale uplift, and further exhumation along the detachment faults of the associated core complexes during the middle to late Miocene. This evolution also resulted in an overprint by epithermal mineralization, and intense advanced argillic alteration.

\begin{abstract}
Acknowledgements The authors would like to thank Fabio Capponi for XRF analyses (University of Geneva) and Peter Laznicka (Metallogenica Consulting Adelaide), Cüneyt Baran, Fatih Pekdemir, and Oktay Parlak (MTA) for help during fieldwork. Panagiotis Voudouris and Albrecht von Quadt are thanked for their valuable comments and suggestions that allowed us to improve the manuscript. We also thank associated editor Frank Melcher for final edits. The research was supported by the "Hacettepe University Scientific Research Coordination Unit" grants FHD-2015-7509 and FDS-2015-7004, and the "Swiss National Science Foundation" through research grants 200020-155928. This research was also partially supported by the General Directorate of Mineral Research and Exploration, Turkey (MTA)-ETI Mine Works during the joint project 2002-32-57.d1. David Selby acknowledges the TOTAL endowment fund. Seçil Delibaș and Burcu Kahraman (Hacettepe University) are thanked for providing various pieces of information allowing us to finalize the manuscript. This paper is dedicated to the memory of the senior author Okan Delibaş, who dramatically passed away in August 2016 during the final revision stages of the manuscript. Okan still had so many scientific projects in mind, his death is a big loss to all of us, including his family, friends, colleagues and the international scientific community.
\end{abstract}

\section{References}

Aghazadeh M, Hou Z, Badrzadeh Z, Zhou L (2015) Temporal-spatial distribution and tectonic setting of porphyry copper deposits in Iran: constraints from zircon $\mathrm{U}-\mathrm{Pb}$ and molybdenite $\mathrm{Re}-\mathrm{Os}$ geochronology. Ore Geol Rev 70:385-406

Agostini S, Doglioni C, Innocenti F, Manetti P, Tonarini S, Savaşçın M (2007) The transition from subduction-related to intraplate Neogene magmatism in the western Anatolia and Aegean area. In Beccaluva L, Bianchini G, Wilson M (eds) Cenozoic volcanism in the Mediterranean area. Geol Soc Am Spec Paper 418:1-15

Agostini S, Doglioni C, Innocenti F, Manetti P, Tonarini S (2010) On the geodynamics of the Aegean rift. Tectonophysics 488:7-21
Aizawa Y, Tatsumi Y, Yamada H (1999) Element transport by dehydration of subducted sediments: implication for arc and ocean island magmatism. Island Arc 8:38-46

Akdeniz N, Konak N (1979) Geology of the Simav-Emet-Tavşanl1Dursunbey-Demirci region. Report, General Directorate of Mineral Research and Exploration, Turkey (MTA) Report No: 6547, Ankara (unpublished, in Turkish)

Aldanmaz E, Pearce JA, Thirlwall MF, Mitchell JG (2000) Petrogenetic evolution of late Cenozoic, post-collision volcanism in western Anatolia, Turkey. J Volcanol Geoth Res 102:67-95

Alici P, Temel A, Gourgaud A (2002) Pb-Nd-Sr isotope and trace element geochemistry of quaternary extension-related alkaline volcanism: a case study of Kula region (western Anatolia, Turkey). J Volcanol Geoth Res 115:487-510

Alonso-Perez R, Müntener O, Ulmer P (2009) Igneous garnet and amphibole fractionation in the roots of island arcs: experimental constraints on andesitic liquids. Contrib Mineral Petr 157:541-558

Altunkaynak S,, Dilek Y (2006) Timing and nature of postcollisional volcanism in western Anatolia and geodynamic implications. In: Dilek Y, Pavlides S (eds) Postcollisional tectonics and magmatism in the Mediterranean region and Asia, Geol Soc Am Spec Paper, vol 409, pp 321-351

Altunkaynak Ș, Dilek Y, Genç CȘ, Sunal G, Gertisser R, Furnes H, Foland KA, Yang J (2012a) Spatial, temporal and geochemical evolution of Oligo-Miocene granitoid magmatism in western Anatolia, Turkey. Gondwana Res 21:961-986

Altunkaynak Ş, Sunal G, Aldanmaz E, Genç CŞ, Dilek Y, Furnes H, Foland KA, Yang J, Yildiz M (2012b) Eocene granitic magmatism in NW Anatolia (Turkey) revisited: new implications from comparative zircon SHRIMP U-Pb and ${ }^{40} \mathrm{Ar} /{ }^{39} \mathrm{Ar}$ geochronology and isotope geochemistry on magma genesis and emplacement. Lithos 155 : 289-309

Arikas K, Voudouris P (1998) Hydrothermal alterations and mineralizations of magmatic rocks in the southeastern Rhodope massif. Acta Vulcanol 10:353-365

Audetat A (2010) Source and evolution of molybdenum in the porphyry $\mathrm{Mo}(-\mathrm{Nb})$ deposit at cave peak, Texas. J Petrol 51:1739-1760

Aydoğan MS, Çoban H, Bozcu M, Akinci Ö (2008) Geochemical and mantle-like isotopic ( $\mathrm{Nd}, \mathrm{Sr}$ ) composition of the Baklan granite from the Muratdaği region (Banaz, Uşak), western Turkey: implications for input of juvenile magmas in the source domains of western Anatolia Eocene-Miocene granites. J Asian Earth Sci 33:155-176

Barragan R, Geist D, Hall M, Larson P, Kurz M (1998) Subduction controls on the compositions of lavas from the Ecuadorian Andes. Earth Planet Sci Lett 154:153-166

Bozkurt E (2004) Granitoid rocks of the southern Menderes massif (southwestern Turkey): field evidence for tertiary magmatism in an extensional shear zone. Int J Earth Sci 93:52-71

Bozkurt E, Park RG (1997) Evolution of a mid-tertiary extensional shear zone in the southern Menderes massif, western Turkey. Bull Soc Geol France 168:3-14

Bozkurt E, Sözbilir H (2004) Tectonic evolution of the Gediz Graben: field evidence for an episodic, two-stage extension in western Turkey. Geol Mag 141:63-79

Bozkurt E, Park RG, Winchester JA (1993) Evidence against the core/cover interpretation of the southern sector of the Menderes massif, West Turkey. Terra Nov. 5:445-451

Brenan JM, Shaw HF, Ryerson FJ, Phinney DL (1995) Mineral-aqueous fluid partitioning of trace elements at $900{ }^{\circ} \mathrm{C}$ and $2.0 \mathrm{GPa}$ : constraints on the trace element chemistry of mantle and deep crustal fluids. Geochim Cosmochim Acta 59:3331-3350

Candan O, Çetinkaplan M, Oberhänsli R, Rimmelé G, Akal C (2005) Alpine high-P/low-T metamorphism of the Afyon zone and implications for the metamorphic evolution of western Anatolia, Turkey. Lithos 84:102-124 
Chakrabarti R, Basu AR, Ghatak A (2012) Chemical geodynamics of western Anatolia. Int Geol Rev 54:227-248

Claiborne L, Miller CF, Walker BA, Wooden JL, Mazdab FK, Bea F (2006) Tracking magmatic processes through $\mathrm{Zr} / \mathrm{Hf}$ ratios in rocks and $\mathrm{Hf}$ and Ti zoning in zircons: an example from the Spirit Mountain batholith, Nevada. Mineral Mag 70:517-543

Collins AS, Robertson AHF (1997) Lycian melange, southwestern Turkey: an emplaced late cretaceous accretionary complex. Geology 25:255-258

Condamine P, Médard E (2014) Experimental melting of phlogopitebearing mantle at $1 \mathrm{GPa}$ : implications for potassic magmatism. Earth Planet Sci Lett 397:80-92

Conticelli S, Antonio MD, Pinarelli L, Civetta L, Federico N (2002) Source contamination and mantle heterogeneity in the genesis of Italian potassic and ultrapotassic volcanic rocks : $\mathrm{Sr}-\mathrm{Nd}-\mathrm{Pb}$ isotope data from Roman Province and southern Tuscany. Mineral Petrol 74:189-222

Crusius J, Calvert S, Pedersen T, Sage D (1996) Rhenium and molybdenum enrichments in sediments as indicators of oxic, suboxic and sulfidic conditions of deposition. Earth Planet Sci Lett 145:65-78

Çoban H, Karacik Z, Ece ÖI (2012) Source contamination and tectonomagmatic signals of overlapping early to middle Miocene orogenic magmas associated with shallow continental subduction and asthenospheric mantle flows in western Anatolia: a record from Simav (Kütahya) region. Lithos 140-141:119-141

Davidson J, Turner S, Handley HK, Macpherson C, Dosseto A (2007) Amphibole "sponge" in arc crust? Geology 35:787-790

Davidson J, Turner S, Plank T (2013) Dy/Dy*: variations arising from mantle sources and petrogenetic processes. J Petrol 54:525-537

Delaloye M, Bingöl E (2000) Granitoids from western and northwestern Anatolia: geochemistry and Modeling of geodynamic evolution. Int Geol Rev 42:241-268

Delibaş O, Parlak O, Pekdemir F, Baran C (2012a) The Pınarbaşı granitoid (Gediz-Kütahya) $\mathrm{Mo}-\mathrm{Cu}, \mathrm{Pb}-\mathrm{Zn}$ and $\mathrm{Sb} \pm \mathrm{Ag}$ mineralizations: an example of the polymetallic mineralizations from the mid-west Anatolia. Yerbilimleri 33:151-176 (in Turkish)

Delibaș O, Baran C, Pekdemir F (2012b) Pınarbașı (KütahyaGedizGediz) region 2010-2011 mineral expoloration and ore geology report. General Directorate of Mineral Research and Exploration, Turkey (MTA). Report No: 6580, Ankara (unpublished, in Turkish)

DePaolo DJ (1981) Trace element and isotopic effects of combined wallrock assimilation and fractional crystallization. Earth Planet Sci Lett 53:189-202

Dhont D, Chorowicz J, Luxey P (2006) Anatolian escape tectonics driven by Eocene crustal thickening and Neogene-quaternary extensional collapse in the eastern Mediterranean region. In: Dilek Y, Pavlides S (eds) Postcollisional tectonics and magmatism in the Mediterranean region and Asia, Geol Soc Am Spec Paper, vol 409, pp 441-462

Dilek Y (2006) Collision tectonics of the Mediterranean region: causes and consequences. In: Dilek Y, Pavlides S (eds) Postcollisional tectonics and magmatism in the Mediterranean region and Asia, Geol Soc Am Spec Paper, vol 409, pp 1-13

Dilek Y, Sandvol E (2009) Seismic structure, crustal architecture and tectonic evolution of the Anatolian-African plate boundary and the Cenozoic orogenic belts in the eastern Mediterranean region. In: Murphy JB, Keppie JD, Hynes AJ (eds) Ancient orogens and modern analogues, Geol Soc London Spec Pub, vol 327, pp 127-160

Dilek Y, Altunkaynak Ș (2010) Geochemistry of Neogene-quaternary alkaline volcanism in western Anatolia, Turkey and implications for the Aegean mantle. Int Geol Rev 52:631-655

Dilek Y, Altunkaynak S, Oner Z (2009) Syn-extensional granitoids in the Menderes core complex and the late Cenozoic extensional tectonics of the Aegean province. In: Ring U, Wernicke B (eds) Extending a continent: architecture, rheology and heat budget, Geol Soc London Spec Pub, vol 321, pp 197-223
Doglioni C, Agostini S, Crespi M, Innocenti F, Manetti P, Riguzzi F, Savașçin MY (2002) On the extension in western Anatolia and the Aegean Sea. In: Rosenbaum G, Lister GS (eds) India-Asia convergence in NW Himalaya: reconstruction of the evolution of the alpine-Himalayan orogen, J Virtual Explor, vol 7, pp 167-181

Duggen S, Portnyagin M, Baker J, Ulfbeck D, Hoernle K, GarbeSchönberg D, Grassineau N (2007) Drastic shift in lava geochemistry in the volcanic-front to rear-arc region of the southern Kamchatkan subduction zone: evidence for the transition from slab surface dehydration to sediment melting. Geochim Cosmochim Acta 71:452-480

Eby GN (1992) Chemical subdivision of the A-type granitoids: petrogenetic and tectonic implications. Geology 20:641-644

Erkül F (2010) Tectonic significance of synextensional ductile shear zones within the early Miocene Alaçamdağ granites, northwestern Turkey. Geol Mag 147:611-637

Erkül F, Erkül ST, Ersoy Y, Uysal I, Klötzli U (2013) Petrology, mineral chemistry and $\mathrm{Sr}-\mathrm{Nd}-\mathrm{Pb}$ isotopic compositions of granitoids in the central Menderes metamorphic core complex: constraints on the evolution of Aegean lithosphere slab. Lithos 180-181:74-91

Ersoy EY, Palmer MR (2013) Eocene - Quaternary magmatic activity in the Aegean: implications for mantle metasomatism and magma genesis in an evolving orogeny. Lithos 180-181:5-24

Ersoy EY, Helvacı C, Palmer MR (2010) Mantle source characteristics and melting models for the early-middle Miocene mafic volcanism in western Anatolia: implications for enrichment processes of mantle lithosphere and origin of K-rich volcanism in post-collisional settings. J Volcanol Geoth Res 198:112-128

Foley S (1992) Potassic and ultrapotassic magmas and their origin veinplus-wall-rock melting mechanisms in the lithosphere and the origin of potassic alkaline magmas. Lithos 28:435-453

Furman T, Graham D (1999) Erosion of lithospheric mantle beneath the east African rift system: geochemical evidence from the Kivu volcanic province. Lithos 48:237-262

Fytikas M, Innocenti F, Manetti P, Peccerillo A, Mazzuoli R, Villari L (1984) Tertiary to quaternary evolution of volcanism in the Aegean region. In Dixon JE, Robertson AHF (eds), The geological evolution of the eastern Mditerranean geol soc London spec pub 17:687-699

Green TH (1995) Significance of $\mathrm{Nb} / \mathrm{Ta}$ as an indicator of geochemical processes in the crust-mantle system. Chem Geol 120:347-359

Grove TL, Elkins-Tanton L, Parman SW, Chatterjee N, Müntener O, Gaetani GA (2003) Fractional crystallization and mantle-melting controls on calc-alkaline differentiation trends. Contrib Mineral Petr 145:515-533

Gökce A, Spiro B (1994) Stable isotope study of antimony deposits in the Muratdağ region, western Turkey. Mineral Deposita 29:361-365

Guo Z, Wilson M, Zhang M, Cheng Z, Zhang L (2013) Post-collisional, K-rich mafic magmatism in South Tibet: constraints on Indian slabto-wedge transport processes and plateau uplift. Contrib Mineral Petr 165:1311-1340

Güleç N (1991) Crust-mantle interaction in western Turkey: implications from $\mathrm{Sr}$ and $\mathrm{Nd}$ isotope geochemistry of tertiary and quaternary volcanics. Geol Mag 128:417-435

Gürboğa Ș, Kocyiğit A, Ruffet G, Kocyiĝit A, Ruffet G (2013) Episodic two-stage extensional evolutionary model for southwestern Anatolian graben-horst system: new field data from the ErdoĝmușYenigediz graben (Kütahya). J Geodyn 65:176-198

Harris NB, Kelley S, Okay A (1994) Post-collision magmatism and tectonics in northwest Anatolia. Contrib Mineral Petr 117:241-252

Hasözbek A, Akay E, Erdogan B, Satir M, Siebel W (2010) Early Miocene granite formation by detachment tectonics or not? A case study from the northern Menderes massif (western Turkey). J Geodyn 50:67-80

Helvacı C, Ersoy Y, Sözbilir H, Erkül F, Sümer Ö, Uzel B (2009) Geochemistry and ${ }^{40} \mathrm{Ar} /{ }^{39} \mathrm{Ar}$ geochronology of Miocene volcanic 
rocks from the Karaburun peninsula: implications for amphibolebearing lithospheric mantle source, western Anatolia. J Volcanol Geoth Res 185:181-202

Hetzel R, Ring U, Akal C, Troesch M (1995) Miocene NNE-directed extensional unroofing in the Menderes massif, southwestern Turkey. J Geol Soc Lond 152:639-654

Hofmann AW (1997) Mantle geochemistry: the message from oceanic volcanism. Nature 385:219-229

Hora JM, Singer BS, Wörner G, Beard BL, Jicha BR, Johnson CM (2009) Shallow and deep crustal control on differentiation of calcalkaline and tholeiitic magma. Earth Planet Sci Lett 285:75-86

Hou Z, Zhang H (2014) Geodynamics and metallogeny of the eastern Tethyan metallogenic domain. Ore Geol Rev 70:346-384

Hou Z, Yang Z, Qu X, Meng X, Li Z, Beaudoin G, Rui Z, Gao Y, Zaw K (2009) The Miocene Gangdese porphyry copper belt generated during post-collisional extension in the Tibetan orogen. Ore Geol Rev $36: 25-51$

Hou Z, Zhang H, Pan X, Yang Z (2011) Porphyry Cu(-Mo-Au) deposits related to melting of thickened mafic lower crust: examples from the eastern Tethyan metallogenic domain. Ore Geol Rev 39:21-45

Innocenti F, Agostini S, Di Vincenzo G, Doglioni C, Manetti P, Savașçın MY, Tonarini S (2005) Neogene and quaternary volcanism in western Anatolia: magma sources and geodynamic evolution. Mar Geol 221:97-421

Irvine TN, Baragar WRA (1971) A guide to the chemical classification of the common volcanic rocks. Can J Earth Sci 8(5):523-548

Isik V, Tekeli O, Seyitoglu G (2004) The ${ }^{40} \mathrm{Ar} /{ }^{39} \mathrm{Ar}$ age of extensional ductile deformation and granitoid intrusion in the northern Menderes core complex: implications for the initiation of extensional tectonics in western Turkey. J Asian Earth Sci 23:555-566

Jacobsen SB, Wasserburg GJ (1984) Sm-Nd isotopic evolution of chondrites and achondrites. Earth Planet Sci Lett 67:137-150

Jolivet L, Brun JP (2010) Cenozoic geodynamic evolution of the Aegean. Int J Earth Sci 99:109-138

Jolivet L, Faccenna C, Goffe B, Burov E, Agard P (2003) Subduction tectonics and exhumation of high-pressure metamorphic rocks in the Mediterranean orogens. Am J Sci 303:353-409

Jolivet L, Faccenna C, Huet B, Labrousse L, Le Pourhiet L, Lacombe O, Lecomte E, Burov E, Denèle Y, Brun JP, Philippon M, Paul A, Salaün G, Karabulut H, Piromallo C, Monié P, Gueydan F, Okay A, Oberhänsli R, Pourteau A, Augier R, Gadenne L, Driussi O (2013) Aegean tectonics: strain localisation, slab tearing and trench retreat. Tectonophysics 597-598:1-33

Jolivet L, Menant A, Sternai P, Rabillard A, Arbaret L, Augier R, Laurent V, Beaudoin A, Grasemann B, Huet B, Labrousse L, Le L (2015) The geological signature of a slab tear below the Aegean. Tectonophysics 659:166-182

Kaiser-Rohrmeier M, von Quadt A, Driesner T, Heinrich CA, Handler R, Ovtcharova M, Ivanov Z, Petrov P, Sarov S, Peytcheva I (2013) Post-orogenic extension and hydrothermal ore formation: highprecision geochronology of the central Rhodopian metamorphic core complex (Bulgaria-Greece). Econ Geol 108:691-718

Karabulut H, Paul A, Afacan ET, Hatzfeld D, Childs DM, Aktar M (2013) Long-wavelength undulations of the seismic Moho beneath the strongly stretched western Anatolia. Geophys J Int 194:450-464

Karaoğlu Ö, Helvacı C (2014) Isotopic evidence for a transition from subduction to slab-tear related volcanism in western Anatolia, Turkey. Lithos 192-195:226-239

Karaoğlu Ö, Helvac1 C, Ersoy EY (2010) Petrogenesis and ${ }^{40} \mathrm{Ar} /{ }^{39} \mathrm{Ar}$ geochronology of the volcanic rocks of the Ușak-Güre basin, western Turkey. Lithos 119:193-210

Kay S, Mpodozis C (2001) Cenrtal Andean ore deposits linked to evolving shallow subduction systems and thickening crust. Geol Soc Am Today 11:4-9

Keppler H (1996) Constraints from partitioning experiments on the composition of subduction-zone fluids. Nature 380:237-240
Klaver M, Djuly T, de Graaf S, Sakes A, Wijbrans J, Davies G, Vroon P (2015) Temporal and spatial variations in provenance of eastern Mediterranean Sea sediments: implications for Aegean and Aeolian arc volcanism. Geochim Cosmochim Acta 153:149-168

Koçyiğit A, Unay E, Sarac G (2000) Episodic graben formation and extensional neotectonic regime in west-central Anatolia and the Isparta angle: a case study in the Aksehir-Afyon graben, Turkey. In Bozkurt E, Winchester JA, Piper JDA (eds) Tectonics and magmatism in Turkey and surrounding area, Geol Soc London Spec Pub 173:405-421

Koprubasi N, Aldanmaz E (2004) Geochemical constraints on the petrogenesis of Cenozoic I-type granitoids in northwest Anatolia, Turkey: evidence for magma generation by lithospheric delamination in a post-collisional setting. Int Geol Rev 46:705-729

Kroll T, Muller D, Seifert T, Herzig PM, Schneider A (2002) Petrology and geochemistry of the shoshonite-hosted Skouries porphyry $\mathrm{Cu}-$ Au deposit, Chalkidiki, Greece. Mineral Deposita 37:137-144

Kuşçu İ, Gençalioğlu-Kuşçu G, Tosdal R, Ulrich T, Freidman R (2011) The geochronolgy of gold-copper deposition and temporal association with magmatic rocks in western Anatolia. 64th Geological Congress of Turkey, Ankara, April 25-29, 2011. Abstracts book: 189-190

Lan CY, Lee T, Wang Lee C (1990) The Rb-Sr isotopic record in Taiwan gneisses and its tectonic implication. Tectonophysics 183:129-143

Lloyd FE, Arima M, Edgar AD (1985) Partial melting of a phlogopiteclinopyroxenite nodule from south-West Uganda: an experimental study bearing on the origin of highly potassic continental rift volcanics. Contrib Mineral Petr 91:321-329

Macpherson CG, Dreher ST, Thirlwall MF (2006) Adakites without slab melting: high pressure differentiation of island arc magma, Mindanao, the Philippines. Earth Planet Sci Lett 243:581-593

Mao JW, Pirajno F, Xiang JF, Gao JJ, Ye HS, Li YF, Guo BJ (2011) Mesozoic molybdenum deposits in the east Qinling-Dabie orogenic belt: characteristics and tectonic settings. Ore Geol Rev 43:264-293

Marchev P, Kaiser-Rohrmeier B, Heinrich C, Ovtcharova M, von Quadt A, Raicheva R (2005) Hydrothermal ore deposits related to postorogenic extensional magmatism and core complex formation: the Rhodope massif of Bulgaria and Greece. Ore Geol Rev 27:53-89

Márton I, Moritz R, Spikings R (2010) Application of low-temperature thermochronology to hydrothermal ore deposits: formation, preservation and exhumation of epithermal gold system from the eastern Rhodopes, Bulgaria. Tectonophysics 483:240-254

Middlemost EAK (1994) Naming materials in the magma/igneous rock system. Earth Sci Rev 37:215-224

Moritz R, Márton I, Ortelli M, Marchev P, Voudouris P, Bonev N, Spikings R, Cosca M (2010) A review of age constraints of epithermal precious and base metal deposits of the tertiary eastern Rhodopes: coincidence with late Eocene-early Oligocene tectonic plate reorganization along the Tethys. In: Christofides G, Kantiradis N, Kostopoulos DS, Chatziperos AA (eds) Proceedings of the XIX congress of the Carpathian Balkan geological association. Scientific Annals of the School of Geology, Thessaloniki, pp 351-358

Moritz R, Noverraz C, Marton I, Marchev P, Spikings RA, Fontignie DA, Spangenberg JE, Vennemann T, Kolev K, Hasson S (2014) Sedimentary-rock-hosted epithermal systems of the tertiary eastern Rhodopes, Bulgaria: new constraints from the Stremtsi gold prospect. In Garofalo PS, Ridley JS (eds) Gold-transporting hydrothermal fluids in the Earth's crust, Geol Soc London Spec Pub 402:207-230

Moritz R, Rezeau H, Ovtcharova M, Tayan R, Melkonyan R, Hovakimyan S, Ramazanov V, Selby D, Ulianov A, Chiaradia M, Putlitz B (2016) Long-lived, stationary magmatism and pulsed porphyry systems during Tethyan subduction to post-collision evolution in the southernmost lesser Caucasus, Armenia and Nakhitchevan. Gondwana Res 37:465-503 
Müller D, Groves DI (2016) Potassic igneous rocks and associated goldcopper mineralization. Springer 4th ed, 311

Mutlu AK, Karabulut H (2011) Anisotropic Pn tomography of Turkey and adjacent regions. Geophys J Int 187:1743-1758

Mutlu H, Sariz K, Kadir S (2005) Geochemistry and origin of the Şaphane alunite deposit, western Anatolia, Turkey. Ore Geol Rev 26:39-50

Okay A (2008) Geology of Turkey : a synopsis. Anschnitt 21:19-42

Okay A, Tüysüz O (1999) Tethyan sutures of northern Turkey. In Durand B, Jolivet L, Horvath F, Seranne M (eds) The Mediterranean basin: tertiary extension within the alpine orogen. Geol Soc London Spec Pub 156:475-515

Okay A, Satir M, Maluski H, Siyako M, Monie P, Metzger R, Akyüz S (1996) Paleo-and neo-Tethyan events in northwestern Turkey: geologic and geochronologic constraints. In Yin A, Harrison TM (eds) The tectonic evolution of Asia. Cambridge University press, $p 420$ 441

Okay A, Harris NBW, Kelley SP (1998) Exhumation of blueschists along a Tethyan suture in Northwest Turkey. Tectonophysics 285:275-299

Oygür V (1997) Anatomy of an epithermal mineralization: Mumcu (Balıkesir-Sındırgı), inner-western Anatolia, Turkey. Miner Res Expl Bull 119:29-39

Oygür V, Erler A (2000) Metallogeney of Simav graben (inner-western Anatolia, Turkey). Geol Bull Turkey 43:7-19

Oyman T, Özgenç I, Tokcaer M, Akbulut M (2013) Petrology, geochemistry, and evolution of the iron skarns along the northern contact of the Eğrigöz plutonic complex, western Anatolia, Turkey. Turk J Earth Sci 22:61-97

Öner Z, Dilek Y (2011) Supradetachment basin evolution during continental extension: the Aegean province of western Anatolia, Turkey. Geol Soc Am Bull 123:2115-2141

Patchett PJ, Vervoort JD, Söderlund U, Salters VJM (2004) Lu-Hf and $\mathrm{Sm}-\mathrm{Nd}$ isotopic systematics in chondrites and their constraints on the Lu-Hf properties of the earth. Earth Planet Sci Lett 222:29-41

Patiño Douce AE (1999) What do experiments tell us about the relative contributions of crust and mantle to the origin of granitic magmas? In Castro A, Fernandez C, Vigneresse JL (eds), Understanding granites: integrating new and classical techniques. Geol Soc London Spec Pub 168:55-75

Pe-Piper G, Piper DJW (2001) Late Cenozoic, post-collisional Aegean igneous rocks: $\mathrm{Nd}, \mathrm{Pb}$ and $\mathrm{Sr}$ isotopic constraints on petrogenetic and tectonic models. Geol Mag 138:653-668

Pe-Piper G, Piper DJW (2007) Neogene backarc volcanism of the Aegean: new insights into the relationship between magmatism and tectonics. In Beccaluva L, Bianchini G, Wison M (eds) Cenozoic volcanism of the Aegean: new insights into the relationship between magmatism and tectonics. Geol Soc Am Spec Paper 418:17-31

Pearce JA (1983) Role of the sub-continental lithosphere in magma genesis at active continental margins. In: Hawkesworth CJ, Norry MJ (eds) Continental basalts and mantle xenoliths. Shiva Publishing LTd, Cambridge, pp 230-249

Pearce JA, Peate DW (1995) Tectonic implications of the composition of volcanic arc magmas. Annu Rev Earth Planet Sci 23:251-285

Peccerillo A, Taylor SR (1976) Geochemistry of Eocene calc-alkaline volcanic rocks from the Kastamonu area, northern Turkey. Contrib Mineral Petr 58:63-81

Perello J, Cox D, Garamjav D, Sanjdorj S, Diakov S, Schissel D, Munkhbat TO, Oyun G (2001) Oyu Tolgoi, Mongolia: SiluroDevonian porphyry $\mathrm{Cu}-\mathrm{Au}(\mathrm{Mo})$ and high-sulfidation $\mathrm{Cu}$ mineralization with a cretaceous chalcocite blanket. Econ Geol 96:14071428

Pettke T, Oberli F, Heinrich CA (2010) The magma and metal source of giant porphyry-type ore deposits, based on lead isotope microanalysis of individual fluid inclusions. Earth Planet Sci Lett 296:267-277

Plank T (2005) Constraints from thorium/lanthanum on sediment recycling at subduction zones and the evolution of the continents. J Petrol 46:921-944

Plank T, Langmuir C (1993) Tracing trace elements from sediment input to volcanic output at subduction zones. Nature 362:739-742

Plank T, Langmuir C (1998) The chemical composition of subducting sediment and its consequences for the crust and mantle. Chem Geol 145:325-394

Pourteau A, Candan O, Oberhänsli R (2010) High-pressure metasediments in Central Turkey: constraints on the Neotethyan closure history. Tectonics 29:TC5004

Rabayrol F, Miskovic A, Hart CJR, Kuscu İ, Sanchez M (2014) The Cenozoic metallogeny of Western Anatolia, Turkey. SEG 2014 Meeting: Building Exploration Capability for the twenty-first Century, Keystone, Colorado, USA, September 27-30 2016. http://www.segweb.org/SEG/_Events/Conference_Website_ Archives/2014/Conference Proceedings/data/index.htm, poster 0393-000197

Rapp RP, Watson EB, Miller CF (1991) Partial melting of amphibolite/ eclogite and the origin of Archean trondhjemites and tonalites. Precambrian Res 51:1-25

Rezeau H, Moritz R, Wotzlaw JF, Tayan R, Melkonyan R, Ulianov A, Selby D, d'Abzaz FX, Stern R (2016) Temporal and genetic link between incremental pluton assembly and pulsed porphyry $\mathrm{Cu}-\mathrm{Mo}$ formation in accretionary orogens. Geology 44:627-630

Ribeiro JM, Stern RJ, Kelley KA, Martinez F, Ishizuka O, Manton WI, Ohara Y (2013) Nature and distribution of slab-derived fluids and mantle sources beneath the Southeast Mariana forearc rift. Geochem Geoph Geos 14:4585-4607

Richards JP (2009) Postsubduction porphyry $\mathrm{Cu}-\mathrm{Au}$ and epithermal $\mathrm{Au}$ deposits: products of remelting of subduction-modified lithosphere. Geology 37:247-250

Richards JP (2011) Magmatic to hydrothermal metal fluxes in convergent and collided margins. Ore Geol Rev 40:1-26

Richards JP, Mumin AH (2013) Magmatic-hydrothermal processes within an evolving earth: iron oxide-copper-gold and porphyry $\mathrm{Cu} \pm \mathrm{Mo} \pm \mathrm{Au}$ deposits. Geology 41:767-770

Ring U, Collins AS (2005) U-Pb SIMS dating of synkinematic granites: timing of core-complex formation in the northern Anatolide belt of western Turkey. J Geol Soc Lond 162:289-298

Ring U, Gessner K, Güngör T, Passchier CW (1999) The Menderes massif of western Turkey and the Cycladic massif in the Aegean - do they really correlate? J Geol Soc Lond 156:3-6

Ring U, Johnson C, Hetzel R, Gessner K (2003) Tectonic denudation of a late cretaceous-tertiary collisional belt: regionally symmetric cooling patterns and their relation to extensional faults in the Anatolide belt of western Turkey. Geol Mag 140:421-441

Ring U, Glodny J, Will T, Thomson S (2010) The Hellenic subduction system: high-pressure metamorphism, exhumation, normal faulting, and large-scale extension. Annu Rev Earth Planet Sc 38:45-76

Roberts MP, Clemens JD (1993) Origin of high-potassium, calc-alkaline, I-type granitoids. Geology 21:825-828

Rudnick RL, Gao S (2003) Composition of the continental crust. In Rudnick RL, Holland HD, Turekian KK (eds), The crust, Treatise on Geochemistry, Elsevier.p 1-64

Sánchez MG, McClay KR, King AR, Wijbrams JR (2016) Cenozoic crustal extension and its relationship to porphyry $\mathrm{Cu}-\mathrm{Au}-(\mathrm{Mo})$ and epithermal $\mathrm{Au}-(\mathrm{Ag})$ mineralization in the Biga peninsula, northwestern Turkey. In: Richards JP (ed), Tectonics and metallogeny of the Tethyan orogenic belt, Soc Econ Geol Spec Pub 19:113-156

Seyitoglu G (1997) The Simav Graben: an example of young E-W trending structures in the late Cenozoic extensional system of W. Turkey. Turk J Earth Sci 6:135-141 
Seyitoglu G, Scott BC, Rundle CC (1992) Timing of Cenozoic extensional tectonics in West Turkey. J Geol Soc Lond 149:533-538

Sherlock SC (1999) Oscillatory zoned chrome lawsonite in the Tavşanlı zone, Northwest Turkey. Mineral Mag 63:687-692

Sillitoe RH (2002) Some metallogenic features of gold and copper deposits related to alkaline rocks and consequences for exploration. Mineral Deposita 37:4-13

Smoliar MI, Walker RJ, Morgan JW (1996) Re-Os ages of group IIA, IIIA, IVA, and IVB iron meteorites. Science 271:1099-1102

Spakman W, Wortel MJR, Vlaar NJ (1988) The Hellenic subduction zone: a tomographic image and its geodynamic implications. Geophys Res Lett 15:60-63

Sun SS, McDonough WF (1989) Chemical and isotopic systematics of oceanic basalts: implications for mantle composition and processes. In Saunders AD, Norry MJ (eds) Magmatism in the ocean basins. Geol Soc London Spec Pub 42:313-345

Șengör AMC, Yilmaz Y (1981) Tethyan evolution of Turkey: a plate tectonic approach. Tectonophysics 75:181-241

Şengör AMC, Satir M, Akkök R (1984) Timing of tectonic events in the Menderes massif, western Turkey: implications for tectonic evolution and evidence for pan-African basement in Turkey. Tectonics 3 : 693-707

Tatsumi Y, Hamilton DL, Nesbitt RW (1986) Chemical characteristics of fluid phase released from a subducted lithosphere and origin of arc magmas: evidence from high-pressure experiments and natural rocks. J Volcanol Geoth Res 29:293-309

Thirwall M, Smith TE, Graham AM, Theodorou N, Hollings P, Davidson JP, Arculus RD (1994) High field strength element anomalies in arc lavas: source or processes. J Petrol 35:819-838

Thorpe RS, Francis PW (1979) Variations in Andean andesite compositions and their petrogenetic significance. Tectonophysics 57:53-70

Tokay M, Doyuran V (1979) Seismotectonic features of Gediz and its surroundings. Geol Bull Turkey 22:209-210 (in Turkish with English abstract)

van Hinsbergen DJJ (2010) A key extensional metamorphic complex reviewed and restored: the Menderes massif of western Turkey. Earth-Sci Rev 102:60-76

van Hinsbergen DJJ, Schmid SM (2012) Map view restoration of Aegean-west Anatolian accretion and extension since the Eocene. Tectonics 31:TC5005
Vigneresse JL (2007) The role of discontinuous magma inputs in felsic magma and ore generation. Ore Geol Rev 30:181-216

Voudouris P, Melfos V, Moritz R, Spry PG, Ortelli M, Kartal T (2010) Molybdenite occurrences in Greece: mineralogy, geochemistry and rhenium content. In: Christofides G, Kantiradis N, Kostopoulos DS, Chatziperos AA (eds) Proceedings of the XIX congress of the Carpathian Balkan geological association. Scientific Annals of the School of Geology, Thessaloniki, pp 369-378

Voudouris P, Melfos V, Spry PG, Kartal T, Schleicher H, Moritz R, Ortelli M (2013a) The Pagoni Rachi/Kirki Cu-Mo $\pm \mathrm{Re} \pm \mathrm{Au}$ deposit, northern Greece: mineralogical and fluid inclusion constrains on the evolution of a telescoped porphyry-epithermal system. Can Mineral 51:411-442

Voudouris P, Melfos V, Spry PG, Bindi L, Moritz R, Ortelli M, Kartal T (2013b) Extremely Re-rich molybdenite from porphyry $\mathrm{Cu}-\mathrm{Mo}-\mathrm{Au}$ prospects in northeastern Greece: mode of occurrence, causes of enrichment, and implications for gold exploration. Minerals 3: 165-191

Wasserburg G, Jacousen S, DePaolo D, McCulloch M, Wen T (1981) Precise determination of $\mathrm{Sm} / \mathrm{Nd}$ ratios, $\mathrm{Sm}$ and $\mathrm{Nd}$ isotopic abundances in standard solutions. Geochim Cosmochim Acta 45:23112323

Whitney DL, Bozkurt E (2002) Metamorphic history of the southern Menderes massif, western Turkey. Bull Geol Soc Am 114:829-838

Yiğit Ö (2006) Gold in Turkey — a missing link in Tethyan metallogeny. Ore Geol Rev 28:147-179

Yiğit Ö (2009) Mineral deposits of Turkey in relation to Tethyan metallogeny: implications for future mineral exploration. Econ Geol 104:19-51

Yilmaz Y (1989) An approach to the origin of young volcanic rocks of western Turkey. In: Şengör AMC (ed), Tectonic evolution of the Tethyan region. SE - 10, NATO ASI Series. Springer: 159-189

Zartman RE, Doe BR (1981) Plumbotectonics — the model. Tectonophysics 75:135-162

Zhao JH, Zhou MF (2007) Geochemistry of Neoproterozoic mafic intrusions in the Panzhihua district (Sichuan Province, SW China): implications for subduction-related metasomatism in the upper mantle. Precambrian Res 152:27-47

Zindler A, Hart S (1986) Chemical geodynamics. Annu rev. Earth Planet Sci 14:493-571 